\title{
THE IICHENS OF NORTH CENTRAL OKLAHOMA
}

\section{BY DARVIN WENDELL KECK}

Submitted to the Faculty of the Graduate School of Oklahoma State University in partial fullfillment of the requirements for the degree of DOCTOR OF PHILOSOPHY August, 1961

Over 1,000 specimens of lichens were collected at 78 collecting stations in 11 counties of North Central Oklahoma during 1959 and 1960. The objectives were to identify lichens collected in the area; to establish a record of lichen distribution for each county in the area; and to analyze the ecological relationships.

One hundred eleven species and varieties were identified, representing 34 genera and 20 familiies. Species occurring in each county were Candelaria fibrosa, Parmelia bolliana, Physcia syncolla, Teloschistes chrysophthalomus, and Xanthoria candelaria. Only ten other species occurred in eight or more counties, while 64 species were found in three counties or less and 30 of these were found in only one county each. The number of species per county varied from a low of 19 in Kingfisher County to a high of 77 in Osage County. The variation was very closely correlated to the two physiographic regions of the area. The five counties largely contained in the Sandstone Hills varied between 41 and 77 species with an average of 50 . The six counties in the Redbeds Plains had between 19 and 33 species with an average of 26 .

This variation between regions is correlated to rainfall which averages near 40 inches per year at the eastern boundary of the Sandstone Hills, but only 30 inches at the western boundary of the Redbeds Plains. Other factors, conditioned by rainfall, and also having an influence on lichen growth are the presence of trees, the kinds of rock, and the acidity of the soil. 


\section{INTRODUCTION}

\section{Historical Background}

The term "lichen" was used by Theophrastus (371-287

B.C.), in his History of Plants, to signify a superficial growth on the bark of trees. It referred to hepatics of the Marchantia type rather than to the lichens as they are currently understood. He did, however, describe a species of Roccella, and another of Usnea or Alectoria, which is perhaps the earliest known reference to lichens.

Lichens were alluded to by only a few writers during the next 2000 years. This reflected not only the small amount of study in natural history, but also the relative lack of economic worth of lichens (28).

Schneider (27) in 1897 wrote a history of lichenology, recognizing the following periods:

I. From the earliest times to the end of the seventeenth century.

II. From 1694, when Tournefort, the first to separate lichens taxonomically from the bryophytes, arranged plants into classes called genera, to 1729.

III. From 1729, when Micheli divided lichens into different orders, to 1779.

IV. From 1779, when Weber established definite and reasoned lichen genera based on the structure of thallus and fruits, to 1825.

$V$. From 1825, when $W$ allroth and Meyer each published works dealing with detailed morphological, ecological, and biochemical observations, to 1868 .

VI. From 1868, when Schwendener discovered the dual nature of lichens, to 1894.
Other notable milestones could include the arrangement of all known lichens under their respective genera by Acharius in 1803, and the use of spore characters in classification by De Notaris in 1846 .

The discovery of the dual nature of lichens by Schwendener, in 1868, is often considered to be the beginning of modern lichenology. This discovery led to a wide variety of ideas about classification. This was demonstrated in a report by Fink (8) who conducted a survey of leading botanists and lichenologists throughout the world in an attempt to analyze ideas regarding the relationship of lichen components. Ideas expressed included the following: lichens are a distinct group of organisms and should be separated from fungi; lichens should be classified in the fungus genera that they closely resemble; and, lichens have a definite relationship to fungi, but for convenience should be kept separated from the fungi.

Fink (9) gave his own idea in the following statement: "The lichen is a fungus which lives all or a part of its life in parasitic relation with an algal host and also sustains a relation with an organic or an inorganic substratum." This idea has not been widely accepted, and, despite Fink's 
insisting that a lichen was a fungus, he never attempted to place lichens in existing fungus genera. Perhaps a more widely accepted idea was given by Imshaug (22) who defined a lichen as "an entity capable of reproducing itself, and consisting of two organisms, an alga and a fungus, living together in a state of symbiosis, as is manifested by some change in the anatomy, morphology, or physiology of at least one of its components."

Ideas in regard to the relationship of lichen components, which in turn have influenced taxonomic ideas, have been further complicated by the observance of some lichens that are apparently parasitic on other plants, and even on other lichens.

While the relationship between lichens and fungi has long been recognized, no serious attempt has been made to place lichens in recognized fungus genera.

other problems are related to growth form and to chemistry. Some workers make no distinction on growth form, but a more common approach is to separate groups purely on that basis (i.e., "foliose", "fruticose", "squamulose").

Lichens are also known to contain a great many unique chemicals, and in recent times considerable emphasis has been placed on the chemistry of lichen
Oklahoma Native Plant Record Volume 6, Number 1, December 2006

substances as an aid to lichen taxonomy. This is well illustrated by the work of Asahina (1), and by the use of chemical tests in almost all keys identifying lichens.

It is not, however, been accepted without opposition, as indicated by the following statement by Nearing (25):

Chemical dyes determine nothing, and in most cases differentiate species only from certain artificial "Species" invented for the purpose of being thus differentiated. In certain cases chemicals may be suggestive and helpful, but the naming of hundreds of "species" on the basis of chemical reactions alone, is in itself sufficient proof that the reactions do not coincide with evident relationships, that all determinations should rest on botanical characters, or else all on chemical, which last, of course, would be absurd, but no more absurd than the present mixing of the two methods.

This likely represents an extreme view, but does illustrate the diversity of ideas relating to the classification of lichens.

Because of the uniqueness of lichens, it is understandable that serious problems still exist in lichen taxonomy; much work remains to be done before they can be satisfactorily solved.

In the United States, lichen studies have been confined mostly to the east, north, and Pacific coast areas with the southwest largely being bypassed. oklahoma has barely 100 species reported from about one fourth of its 77

Keck, D.W. 
counties, and no one has attempted to do a complete floristic work for even one county. Kansas had less than 40 species reported until Fearing (7) collected 163 taxa including about 140 species. He suggested that this was perhaps only one third of the total lichens in the state. Arkansas and Texas each has had only a few species reported. This compares with 245 species reported from Ohio by Wolfe (34), and 335 species reported from Washington by Howard (21), although neither suggested the work was complete in those states.

It has always been customary to report the substrate from which a particular lichen was collected. While the finer details of environment were not included, this has at least served as a beginning for ecological studies. In recent times specific observations have been made about light, temperature, humidity, and other factors in regard to various lichen species, although little work has been done on the microenvironment.

Because of the limited literature on lichens in the southwest, and more especially in oklahoma, the need for this present work was seen.

\section{REVIEW OF IITERATURE}

Previous studies involving the lichens of Oklahoma have been very limited. Only two earlier studies have been made wherein appreciable numbers of lichens from Oklahoma were collected and identified.

The first of these was by Hedrick (20), who identified specimens that Prof. Robert

Stratton from oklahoma state University collected from Cimarron, Delaware, Harmon, Johnston, Kay, Mayes, McCurtain, Murray, Osage, Payne, and Roger Mills counties. These counties are widespread throughout the state and represent a great diversity of habitats; however, no attempt was made to collect all the species occurring in any area or county. This study included 59 species. A majority of these were crustose forms occurring on rocks, with Lecidea, Caloplaca, Buellia, and Lecanora being the genera most frequently represented.

The second work was by Hale (16) who collected during 1955-1956 in six contiguous counties in eastern Oklahoma as part of a study of lichens in the Ozarks. These counties were Adair, Cherokee, LeFlore, McCurtain, Pushmataha, and Sequoyah. This study involved "Macrocorticolous" lichens and included 47 species, 
primarily from the genera: Parmelia, Physica, Usnea, Anaptychia, Leptogium, and Pannaria.

Since the latter study dealt exclusively with foliose and fruticose lichens growing on trees, and the previous study dealt largely with crustose forms, there was little duplication of species collected. Only seven species were common to both lists, and collectively these two efforts totaled 99 species.

In addition to these two reports, a few additional specimens representing eight other species and involving the additional counties of Comanche, Noble, and Carter have been reported in monographs by Berry (2), Imshaug (22), and Thomason (31), and in other articles by Hale $(11,14,15,18)$. This gives a total of 107 species reported from Oklahoma and involves 19 of the 77 counties where at least some collecting is known to have been done.

Specimens reported by Hedrick are in the herbarium at the University of Michigan, and those collected by Hale are at the Smithsonian Institution. Other Oklahoma specimens are preserved in herbaria of the Missouri Botanical Garden, New York Botanical Garden, University of Wisconsin, and the private herbarium of $\mathrm{C}$. W. Dodge at st. Louis.
Oklahoma Native Plant Record Volume 6, Number 1, December 2006

\section{THE STUDY AREA}

\section{Location and Size}

The area involved in this study includes the following 11 counties: Creek, Garfield, Grant, Kay, Kingfisher, Lincoln, Logan, Noble, Osage, Pawnee, and Payne. It is situated in North Central Oklahoma (Fig. 1). It is near-rectangular in shape, and is about 115 miles long (east to west), and averages 95 miles wide with the greatest width being about 105 miles. It covers almost 11,000 square miles which is between one sixth and one seventh of the total area of oklahoma.

The area of each county, in square miles, as computed from General Highway County Maps prepared by the Oklahoma Department of Highways is as follows:

\begin{tabular}{cc} 
County & Total Area \\
\hline & (Sq. \\
Creek $)$ \\
Garfield & 988 \\
Grant & 1068 \\
Kay & 1008 \\
Kingfisher & 938 \\
Lincoln & 910 \\
Logan & 967 \\
Noble & 771 \\
Osage & 750 \\
Pawnee & 2393 \\
Payne & 597 \\
\end{tabular}

\section{Physiographic Regions}

Bruner (3) divided the area into two physiographic regions: the Sandstone Hill region which occupies

Keck, D.W. 
approximately the eastern 40

per cent of the area (Fig.

$2)$, and the Redbeds Plains.

These regions are not

sharply delimited;

therefore, a wide zone

characterized by features of

both regions is noticeable.

The Sandstone Hills region

is composed largely of

weathered Pennsylvanian

shales, with rough low hills

of the more resistant

sandstone remaining. Maximum

height of these hills is 300 to 400 feet, although the average is much less. Large sandstone blocks cover the tops and slopes of hills. The broader flat-topped ridges have soil of sufficient depth to support good plant growth.

The Redbeds Plains are composed of soft red Permian clays and shales, with some thin sandstones which are usually so soft that they do not prduce escarpments. This region is primarily one of the rolling plains where hills seldom exceed 100 feet in height. The slightly rolling plain to the west is in contrast to the greater relief near and in the Sandstone Hills region.

\section{Climate and Vegetation}

North Central Oklahoma has a continental type of weather which is characterized by a

pronounced seasonal range in temperature. It has a mean January temperature of $34^{\circ}-$ $39^{\circ} \mathrm{F}$ and a mean July

temperature of $80^{\circ}-82^{\circ} \mathrm{F}$.

Extremes in temperature vary

from several degrees below $0^{\circ} \mathrm{F}$ to somewhat over $100^{\circ} \mathrm{F}$. There

is an average of 200-220

frost-free days throughout the area (32).

Rainfall averages vary from about 30 inches per year in the west to 40 in the east, with considerable year-toyear variation.

There is also an accompanying small increase in relative humidity toward the east.

The Sandstone Hills region is covered with a

transitional oak forest interspersed with grass areas, while the Redbeds Plains region is primarily grassland, with trees usually confined to the flood plains of streams (3). A vegetation map of the area taken from an Oklahoma Game and Fish Department map (Fig. 3).

Higher rainfall and humidity favor the development of most lichens, at least within the limits of conditions found in the study area. Most of the effect is apparently direct since there is a definite change in each category of the lichen flora (terricolous, saxicolous, corticolous) with a change in rainfall. Some of the effect is perhaps related only to tree growth since a few corticolous species are considered to be specific in regard to substrate.

There is also a correlation between rainfall and $\mathrm{pH}$, with

Keck, D.W. 
the eastern part of the study area where the rainfall is greater being primarily acidic and the western part being near neutral to slightly basic. Considerable influence is also exerted on the lichen flora by the pH (17), although this is more related to the microenvironment than to the $\mathrm{pH}$ condition of the general area.

All of these conditions are interrelated and therefore difficult to evalulate individually, but there is a pronounced change in the lichen flora between the eastern and western limits of the study area.

\section{PROCEDURES}

Collecting stations were selected in each county, with desirability as a collecting site being given primary consideration. General County Highway Maps were used to determine the general collecting areas; then a survey of each of these was made to determine a collecting station. This normally consisted of the area immediately around a stream or draw so that collecting could be done from trees, rocks, and partially shaded soil since nearly all lichens grow best on one of these sugbstrates. Less frequently, areas were collected from where rock was the predominant
Oklahoma Native Plant Record Volume 6, Number 1, December 2006

substrate. Observations were also made repeatedly on exposed soil and fence posts, ordinarily near the general collecting areas, but only a very limited number of lichens were found and collected under these conditions.

Consideration was also given to the size of counties so that collecting stations varied in number from four in Pawnee County to 15 in Osage County. This is double the minimum of two collecting stations for any county by Hale (16). An attempt was made to properly distribute these stations within counties and between adjacent counties.

Over 1,000 specimens were collected and are being deposited with the lichen collection in the Department of Botany and Plant Pathology of Oklahoma State University, with duplicates of most of these being kept in the author's private collection.

The seasonal aspect is important primarily because some lichens have mature spores only during certain seasons of the year (28). collecting was done at three different times: (1) from late May to early Auugust, 1959; (2) November, 1959; and (3) April 1960.

Seventy-four collecting stations were visited including at least four stations for each county during the summer. After the degree of repetition was determined to be unusually

Keck, D.W. 
high among neighboring stations used in the summer, it was decided that a considerably smaller number of stations would sufficie during subsequent collection periods. Twenty-one stations were visited during the fall. This included one new station in Kingfisher County, and two stations previously visited in each of the other counties. Eighteen stations including three new areas were visited in the spring. This included at least one in each county. The 78 collecting areas are shown in Fig. 4. Their descriptions, locations, and dates visited are as follows:

1. A wooded hillside near highway 99, two miles northeast of Cleveland, in Osage County, May 25, 1959; November 21, 1959.

2. Along a small stream, three miles south of Wild Horse store in Osage County, May 25, 1959.

3. A wooded hillside with limestone outcrops near highway 20, five miles west of Skiatook, in Osage County, May 25, 1959; April $12,1960$.

4. A blackjack thicket near highway 23, two miles north of Barnsdall in Osage County, May, 25, 1959.

5. Postoak woods, one mile west of Hula Dam near highway 10 in Osage County, May 26, 1959.
6. A wooded ravine near a county road west of highway 99, 12 miles north of Pawhuska in Osage County, May 26, 1959; November 21, 1959' April 13, 1960

7. Along a creek in Osage Hills State Park, two miles south of highway 60 in Osage County, May 26, 1959; April 14,1960 .

8. Sandstone bluffs near highway 99, four miles southeast of Pawhuska in Osage County, May 27, 1959.

9. Sandstone outcrops near highway 20, 12 miles west of Pawhuska in Osage County, May 27, 1959.

10. Along Bird Creek, four miles east of Foraker in Osage County, May 25, 1959.

11. Along a small stream, three miles north and two miles west of Webb City, In Kay County, May 27, 1959.

12. Around Phillips Lake, two miles south of Shidler in Osage County, May 27, 1959.

13. Along the Salt Fork River, two miles south of Lamont in Grant County, May 28, 1959; November 26, 1959.

14. Along Deer Creek, 13 miles north of Lamont in Grant County, May 28, 1959.

15. Along Crooked Creek, three miles west of Wakita in Grant County, May 28, 1959.

16. Along a wooded draw near highway 81, one mile south 
of Medford in Grant County, May 28, 1959.

17. Along the Salt Fork

River, two miles north of Pond Creek in Grant County, May 28, 1959; November 26, 1959 .

18. Along the Salt Fork

River, three miles north of Nash in Grant County, May 29, 1959.

19. A wooded ravine, three miles southeast of

Hillsdale in Garfield County, May 19, 1959.

20. Along Turkey Creek, three miles north of Drummond in Garfield County, May 29, 1959.

21. Along Turkey Creek, eight miles southeast of Drummond in Garfield County, May 29, 1959; November 26, 1959.

22. Along Wolf Creek, three miles southeast of Douglas in Garfield County, May 29, 1959.

23. Open woods near Breckenridge, eight miles northeast of Enid in Garfield County, May 29, 1959 .

24. Along Red Rock Creek, eight miles north of Garber in Garfield County, May 29, 1959.

25. A rocky ravine near highway 64, three miles southeast of Covington in Garfield County, May 29, 1959; April 15, 1960.
26. Postoak woods near highway 33, one mile north of Coyle in Payne County, June 1, 1959.

27. Along Cottonwood Creek, three miles south and onehalf mile west of Guthrie in Logan County, June 1, 1959.

28. Along Bear Creek, onefourth mile west of Meridian in Logan County, June 1, 1959; November 28, 1959.

29. A wooded draw, one-half mile south of highway 105 40 junction, three miles west of Tryon in Lincoln County, June 2, 1959; November 28, 1959.

30. Sandstone outcrops near highway 40, one mile north of Warwick in Lincoln County, June 2, 1959.

31. Along Quapaw Creek north of highway 62, six miles west of Meeker in Lincoln County, June 2, 1959.

32. Postoak woods near highway 18, three miles south of Chandler in Lincoln County, June 2, 1959; November 12, 1959.

33. A persimmon grove, three miles south and one-half mile west of Avery in Lincoln County, June 5, 1959 .

34. Postoak woods near highway 27, three and onehalf miles east of Shamrock in Creek County, June 5, 1959; November 24, 1959.

35. A rocky ravine near the Cimarron River, eight miles

Keck, D.W. 
northeast of Cushing in Payne County, June 5, 1959 .

36. A wooded ravine, one mile west of highway 99 near Arlington in Lincoln County, June 6, 1959; April 11,1960 .

37. Postoak woods, three miles south and nine miles east of Stroud, in Creek County, June 6, 1959.

38. Postoak woods, five miles south and three miles east of Bristow in Creek County, June 6, 1959.

39. A wooded ravine near highway 66, eight miles northeast of Bristow in Creek County, June 6, 1959.

40. Postoak woods, two miles west of Sapulpa and onehalf mile south of highway 66 in Creek County, June 6, 1959 .

41. Along Bridge Creek near highway 51, 21 miles east of Hennessey, in Logan County, June 8, 1959; November 28, 1959.

42. Along Skeleton Creek, seven miles east and two miles south of Hennessey in Kingfisher County, June 8, 1959; November 26, 1959.

\section{Along Turkey Creek, two} miles west of Kingfisher in Kingfisher County, June 8, 1959; November 26, 1959.

44. Postoak woods, two miles southeast of Dover in Kingfisher County, June 8, 1959 .
45. Along Cooper Creek, onehalf mile south of Loyal in Kingfisher County, June 9, 1959 .

46. A wooded draw, two and one-half miles south of highway 33, ten miles west of Kingfisher in Kingfisher County, June 9, 1959.

47. A wooded ravine between highway 33 and the Cimarron River, 15 miles east of Kingfisher in Kingfisher County, June 9, 1959; April $16,1960$.

48. A rocky draw, one mile south of highway $74-33$ junction, ten miles west of Guthrie in Logan County, June 9, 1959.

49. Postoak woods, two miles north of Crescent in Logan County, June 9, 1959; April $16,1960$.

50. Sandstone bluffs near highway 77, eight miles north of Guthrie in Logan Countyk, June 9, 1959.

51. Along Black Bear Creek, one mile north of Morrison in Noble County, June 14, 1959.

52. Along the Arkansas River, ten miles south and three miles east of Ponca City in Noble County, June 13, 1959.

53. A wooded draw, six miles east and three miles south of Billings in Noble County, June 13, 1959; November 26, 1959 .

54. A rocky ravine, near highway 64, five miles west

Keck, D.W. 
of Perry in Noble County, June 13, 1959; April 15, 1960 .

55. A wooded draw, near highway 64, five miles east of Perry in Noble County, June 13, 1959; April 15, 1960 .

56. A wooded ravine, four miles northeast of Ripley in Payne County, June 26, 1959; November 24, 1959; April 11, 1960.

57. A rocky draw near highway 108, four miles south of Glencoe in Payne county, July 7, 1959.

58. A wooded draw, two miles north of Maramec in Pawnee County, July 7, 1959; November 21, 1959.

59. Wooded draw and hillside near highway 64, six miles southeast of Cleveland in Pawnee County, July 7, 1959; April 12, 1960.

60. A wooded ravine near the Arkansas River, one mile north of Blackburn in Pawnee County, July 7, 1959.

61. Sandstone bluffs, along highway 15, eight miles north of Morrison, in Pawnee County, July 7, 1959; November 21, 1959.

62. Along the Arkansas River, five miles southeast of Oilton, in Creek County, August 6, 1959; November $24,1959$.

63. Sandstone bluffs near highway 51, two miles west of Mannford in Creek County, August 6, 1959, April 12, 1960 .

64. A wooded hillside, one mile west of highway 99 and four miles north of Hominy in Osage County, August 6, 1959 .

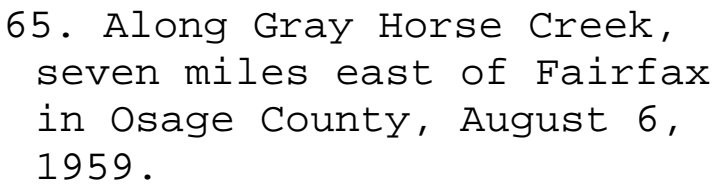

66. Rocky bluffs near the Arkansas River, five miles west of Fairfax in Osage County, August, 6, 1959.

67. Along the Arkansas River near highway 60 , nine miles east of Ponca City in Osage County, August 6, 1959.

68. Along the Salt Fork River near highway 77, five miles northeast of Marland in Kay County, August 8, 1959.

69. Along the Salt Fork River, two miles southwest of Tonkawa in Kay County, August 8, 1959.

70. A wooded draw near highway 11, three miles west of Blackwell in Kay County, August 8, 1959.

71. Along the Chikaskia River, two miles west of Braman in Kay County, August 8 ; , 1959 .

72. Along Deer Creek, four miles northeast of Newkirk in Kay County, August 8, 1959 .

73. Along the Arkansas River, six miles south and six miles east of Newkirk in Kay

Keck, D.W. 
County, August 8, 1959; November 21, 1959; April $13,1960$.

74. A wooded ravine, four miles west and one mile south of Stillwater in Payne County, August 8, 1959; October 9, 1959.

75. A wooded draw near highway 81, seven miles north of Enid in Garfield County, November 26, 1959.

76. Along a rocky wooded draw, one-fourth mile southwest of Tuskegee in Creek County, April 11, 1960 .

77. Along the side and top of a tall rocky hill, one mile west of Mounds in Creek County, April 11, 1960 .

78. Along a rocky draw, six miles northwest of Renfrow in Grant County, April 15, 1960 .

\section{ECOLOGY}

The area studied has many variations in habitat. These include timberland and grassland, a considerable range in average rainfall, different types of rocks such as limestone, sandstone, and loosely compacted silty clay, with shaded and exposed soil, and each having at least some species restricted to that particular environment.

As a consequence of this diversity, few lichen species are widespread in the study area. Only Candelaria fibrosa, Parmelia bolliana, Physcia syncolla, Teloschistes chrysophthalmus, and Xanthoria candelaria were collected in each county. Others which are widely distributed, occurring in at least eight counties, are Acarospora citrina, Caloplaca aurantiaca, Candelaria concolor (two varieties), Lecanora muralis, Parmelia reticulate, Physcia aipolia, $P$. ciliata, $P$. orbicularis, $P$. Tribacoides, and $P$. stellaris.

A total of 64 species were found in three counties or less, and 30 of these were collected in only one county each. Table I lists all species found and their occurrence by counties.

\section{Corticolous Species \\ Growth Forms Foliose}

The foliose forms occurring primarily on trees, but occasionally on rocks, are Anaptychia granulifera, $A$. heterochroa, A. hypoleuca, A. speciosa, Candelaria concolor var. concolor, $C$. concolor var. effuse, C. fibrosa, Collema conglomeratum, $c$. subfurvum, Dermatocarpon tuckermani, Leptogium chloromelum, L. cyanescens, Parmelia bolliana, $P$. caperata, $P$. haitiensis, $P$. reticulate, $P$. rudecta, Physcia aipolia, P. Ciliate, $P$. elaeina, $P$. grisea, $P$. millegrana, $P$. orgicularis, 
P. tribacoides, $P$. stellaris, $P$. syncolla, Pyxine caesiopruinosa, Teloschistes chrysophthalmus (fruticose), and Xanthoria candelaria.

Candelaria concolor, $C$. fibrosa, Parmelia bolliana, P. reticulate, Physcia aipolia, $P$. orbicularis, $P$. tribacoides, $P$. stellaris, P. syncolla, Teloschistes chrysophthalmus, and Xanthoria candelaria occur generally throughout the area with Parmelia bolliana and $P$. reticulate being more abundant in the east (the Sandstone Hills region) than elsewhere, and Physcia aipolia, $P$. syncolla, and Xanthoria candelaria more abundant in the west (the Redbeds Plains area). Extreme east refers to one or more of Creek, Pawnee, and Osage counties. Westernmost refers to one or more of Grant, Garfield, and Kingfisher counties.

Those occurring only in the extreme east include Anapptychia granulifera, $A$. hypoleuca, Dermatocarpon tuckermani, Physcia millegrana, and Pyxine caesiopruinosa.

other occurring over a wider area, but not found in the west are Anaptychia heterochroa, Collema conglomeratum, $C$. subfurvum, Leptogium chloromelum, L. cyanescens, Parmelia caperata, $P$. haitiensis, $P$. rudecta, and Physcia grisea.

The 29 "macro-corticolous" lichens indicate the gradual
Oklahoma Native Plant Record Volume 6, Number 1, December 2006

change from a more luxuriant lichen flora in the Ozarks where Hale (16) collected 63 species, which included all but three of the above group. He found 47 of these in six eastern Oklahoma counties. only 11 of the 29 occur in Grant, Garfield, and Kingfisher counties.

\section{Crustose}

Crustose lichens found on trees include Allarthonia caesia, Buellia punctata, $B$. schaereri, Caloplaca aurantiaca, $C$. cerina, $C$. chrysophthalma, $C$. microphylina, C. ulmorum, Candelariella xanthostigma, Crocynia membranacea, Lecanora hageni, L. piniperda, L. subfusca, L. varia, Lepraria chlorine, Graphis scripta, Pertusaria leioplaca, P. multipuncta, and $P$. pustulata.

Only Caloplaca aurantiaca was found in some abundance throughout the area, while $C$. chrysophthalma, $C$. microphylina, Lecanora hageni, L. varia, Pertusaria leioplaca, $P$. multipuncta, and $P$. pustulata also occurred scattered in several counties. Caloplaca

microphylina occurred only in the west while the others occurred primarily in the east.

Other species were collected infrequently but indicated the following

distributional pattern: Allarthonia caesia, Crocynia membranacea, Lecanora

Keck, D.W. 
piniperda, L. subfusca, Lepraria chlorine, Graphis scripta, Pertusaria leioplaca, P. multipuncta, and $P$. pustulata occurred only in the east, and Candelariella xanthostigma only in the west.

\section{Microhabitat}

Most of the foliose forms were found on rough bark of various woody species although Teloschistes chrysophthalmus and Xanthoria candelaria were often found on dead twigs or bark of dead trees.

Crustose forms were divided into three categories: Caloplaca microphylina, Buellia punctata, and $B$. schaereri which were found $n$ decaying fence posts or old stumps; Allarthonia caesia, Lecanora hageni, L. piniperda, L. subfusca, Graphis scripta, Pertusaria leioplaca, and $P$. pustulata which were found on smooth bark such as the younger parts of hickory (Carya sp.), hackberry (Celtis laevigata), redbud (Cercis canadensis), and red oak (Quercus sp.); and Caloplaca aurantiaca, $c$. cerina, c. ulmorum, and Pertusaria multipuncta which were found on rough bark such as post oak (Quercus stellata), blackjack ( $Q$. marilandica), cottonwood (Populus deltoids), and elm (Ulmus Americana).

\section{Saxicolous Species}

Growth Forms Foliose

Lichen species growing on rocks about equal the number growing on trees, but there is a greater proportion of crustose species. There are only a few that can properly be termed foliose; however, several others which approach this form are called "squamulose" or "nearfoliose". The first term applies to small bits of thallus that have the same morphology as a foliose lichen except that it is much smaller in diameter. The latter term applies to those forms that have a poorly developed thallus in the center but are thicker and lobed at the margins.

Lichens growing on rocks in the above categories are Dermatocarpon miniatum, Endocarpon pusillum, Heppia hassei, Lecanora muralis, L. rubina, Lecidea rufonigra, $L$. russellii, Parmelia conspersa, $P$. isidiata, $P$. obsessa, $P$. stenophylla, Physcia halei, $P$. subtilis, $P$. teretiuscula, and Rinodina oreina.

Lecanora muralis is the only species that occurs throughout the area. There are only a few species in the west but this likely reflects the extreme scarcity of rocks in the three westernmost counties. None of the species occurs primarily in the west, but Lecidea rufonigra, $L$. russellii, Endocarpon

Keck, D.W. 
pusillum, and Heppia hassei are rather intermediate while the other species are found exclusively in the east.

According to Weaver and Clements (33), foliose forms normally follow crustose forms in a xerosere, but Oosting and Anderson (26) indicate that crustose forms sometimes decay a rock in such a way that this succession is not followed. Both conditions were found in the study area.

\section{Crustose}

The crustose rock forms include the following species: Acarospora citrine, A. fuscata, A. smaragdula, Bacidia granosa, B. umbrina, Buellia alboatra, $B$. novomexicana, $B$. retrovertens, $B$. spuria, $B$. stigmaea, B. vilis, Caloplaca arizonica, $C$. decipiens, $C$. flavovirencens, C. lobulata, C. murorum, Candelariella vitellina, Diploschistes actinostomus, d. scruposus, var. scruposus, Lecania californica, L. perproxima, Lecanora atra, L. calcarea, L. dispersa, L. melaena, Lecidea tesselina, Pertusaria pertusa, $P$. velata, Placynthium nigrum, Sarcogyne clavus, $S$. pruinosa, S. simplex, Verrucaria calsiceda, and $V$. nigrescens.

Acarospora citrine, Candelariella vitellina, Diploschistes actinostomus, and Sarcogyne clavus are relatively widespread, but somewhat more abundant in the east. Lecanora calcarea is also widespread, but more frequent in the west. Others occurring less frequently but still not confined to a small area are Acarospora fuscata, Caloplaca flavovirescens, and Lecanora dispersa.

The other species were collected only a few times each, or in a small area, with the following distribution pattern: Acarospora smaragdula, Bacidia granosa, Buellia novomexicana, $B$. spuria, $B$. stigmaea, Lecania californica, Lecanora atra, L. melanea, Pertusaria pertusa, and Verrucaria calciseda are found only in the east, while Buellia alboatra and $B$. vilis are found only in the west. Many in this group occupy an intermediate to somewhat easterly position.

\section{Types of Rock}

Another important consideration is the type of rock. Those species found on limestone are Bacidia granosa, Buellia alboatra, B. vilis, Dermatocarpon miniatum, Heppia hassei, Lecania californica, L. perproxima, Lecanora calcarea, and Verrucaria calsiceda.

Those found on both sandstone and limestone are Acaropsora fuscata, Caloplaca murorum, Endocarpon pusillum,

Keck, D.W. 
Lecanora muralis, Lecidea russellii, Placynthium nigrum, and Sarcogyne pruinosa, while the remaining 35 species in this group are confined to sandstone.

There was a slight north to south variation since most of the limestone was found in the north.

\section{Terricolous Species}

The remaining species of lichens grow on soil or loosely compacted silty clay, sometimes being closely associated with rocks but not attached directly to them.

Included are Cladonia apodocarpa, C. capitata, C. chlorophaea, C. fimbriata, C. subcariosa, C. subtenuis, C. uncialis, Coccocarpia cronia, Dermatocarpon hepaticum, Diploschistes scruposus, var. bryophila, Lecidea decipiens, Peltigera canina, staurothele diffreactella, and $S$. umbrina.

The Cladonia species occur primarily on thin, moist, shaded soil overlying sandstone. Cladonia capitata and $C$. chlorophaea are readily found in the east with $C$. subcariosa being restricted to a smaller area and also of less frequent occurrence. The other species are very infrequent and occur only in the extreme west. No Cladonia species were found in westernmost counties, although sterile, unidentifiable specimens were found only a few miles away in adjacent counties.

Coccocarpia cronia, which also occurs on tree bases, and Diploschistes scruposus var. bryophila occur only in the east and grow among mosses over sandstone.

Staurothele diffractella, s. umbrina, Dermatocarpon hepaticum, and Lecidea decipiens were found on exposed soil, and occur only in the west.

\section{SUMMARY}

Over 1000 specimens of lichens were collected in an 11-county area of North Central Oklahoma during 195960. this included 111 species and varieties representing 34 genera and 20 families. Their identificfation involved the use of 24 monographic studies and other taxonomic

literature. Keys to various taxa and a list of all species are included. The order of listing families

follows Fink (10) with nomenclature following Hale and Culberson (13). Families having the greatest number of species and varieties are Physciaceae 17, Lecanoraceae 14, Parmeliaceae 12, Caloplacaceae 10, and Buelliaceae 9. These five families contain 56 per cent of all species found. Table I shows the distribution by counties for each taxon. A 
tablular view of families is shown in Table II.

The specimens are being deposited with the lichen collection of the Department of Botany and Plant Pathology at oklahoma State University, and duplicates of most of these are in the author's private collection. Only five species were collected in each county, while ten othrs were collected in at least eight counties. Sixty-four species were collected in three counties or less and 30 of these were collected in only one county each. There was a much more luxuriant lichen flora in the east than in the west, with little north to south variation. Ecological relationships are discussed and remarks on location and habitat are given for each species in the "List of Species and Habitats".

Fifty-nine additions were made to the lichen flora of Oklahoma. These are given special reference in the keys.

\section{IIST OF SPECIES AND HABITATS}

[Ed. note: Nomenclature updated in 2006 by Douglas M. Ladd is in brackets]

The order of listing families follows Fink (10) while nomenclature follows Hale and Culberson (13). Each number is a collecting number for a specimen. These are referred to only for species which represent additions to the lichen flora of Oklahoma. When more than one specimen is cited
Oklahoma Native Plant Record Volume 6, Number 1, December 2006

for a species, each substrate is cited only once, and specimens without the substrate immediately following the collecting number have the same substrate as the one previously listed. Taxa preceded by an asterisk have not been previously reported as components of the Oklahoma lichen flora. Those species among this group not followed by special literature citations were not included in other literature pertinent to Oklahoma lichens. (11, 14, $15,16,18,20)$.

\section{Pyrenulales \\ Verrucariaceae}

*Verrucaria calsiceda DC. [= V. calciseda DC.] is represented by Keck 68 on limestone, five miles west of Skiatook, in Osage County.

*Verrucaria nigrescens Pers. is represented by Keck 36 on sandstone, two miles northeast of Cleveland, in Osage County, and by Keck 1075 on limestone, six miles northwest of Renfrow in Grant County .

\section{*Staurothele diffractella}

(Nyl.) Tuck. is represented by Keck 519 on poorly cemented silty clay, 15 miles east of Kingfisher in Kingfisher County .

Staurothele umbrina (Ach.) Tuck. [= S. fissa (Taylor) Zwackh]; on poorly cemented silty clay; Kingfisher county.

Keck, D.W. 
Dermatocarpaceae

* Dermatocarpon hepaticum

(Ach.) Th. Fr. [= Catapyrenium cinereum (Pers.) Körber, but these reports probably refer, at least in part, to Placidium squamulosum (Ach.) Breuss] is represented by Keck 995 on exposed soil, two miles west of Kingfisher in Kingfisher County.

*Dermatocarpon miniatum (L.) Mann. [reports on calcareous substrates probably refer to $D$. muhlenbergii (Ach.) Müll. Arg.] is represented by Keck 76 on limestone, five miles west of Skiatook, in Osage County, and Keck 1056, six miles south and six miles east of Newkirk, in Kay County .

\section{Dermatocarpon tuckermani}

(Rav.) Zahl. [= Placidium arboretum (Michener) Lendemer]; on post oak, in Osage County.

Endocarpon pusillum Hedw. [local reports probably refer to $E$. pallidulum (Nyl.) Nyl.] is represented by Keck 374 on sandstone, one mile north of Warwick in Lincoln County, and by Keck 762 on limestone, four miles northeast of Newkirk in Kay county .

\section{Hysteriales}

Arthoniaceae

*Allarthonia caesia Fw. [= Arthonia caesia (Flotow) Körber] is represented by Keck 915 on persimmon (Diospyros virginiana), five miles southeast of Oilton, in Creek County; by Keck 57 on willow (Salix nigra), three miles south of Wild Horse store, and Keck 849 on redbud, 12 miles north of Pawhuska, both in Osage County.

Graphidaceae

*Graphis scripta (L.) Ach . is represented by Keck 678 on hackberry, one mile northwest of Blackburn in Pawnee County, and by Keck 939 on red oak, four miles northeast of Ripley in Payne county.

\section{Lecanorales}

Diploschistaceae

*Diploschistes actinostomus (Pers. ) Zahl. [(Ach.) Zahlbr.] is represented by Keck 16 on sandstone, two miles east of Cleveland, in Osage County, and by Keck 440, 361, 536, 584, and 672 in Creek, Lincoln, Logan, Noble, and Pawnee counties, respectively.

\section{Diploschistes scruposus} (Schreb.) Norm., var. scruposus; on sandstone; Lincoln, Logan, Osage, and Payne counties.

\section{*Diploschistes scruposus} (Schreb.) Norm., var. bryophila (Ehrh.) Ach. [= D. muscorum (Scop.) R. Sant.] is represented by Keck 792 over mosses, five miles southwest of Stillwater in Payne County, and by Keck 345 over Cladonia sp. three and onehalf miles southwest of Tryon in Lincoln County.

Collemaceae (5)

Collema conglomeratum Hoffm.: on post oak; Lincoln, 
Pawnee, Lincoln, Pawnee, and Payne counties.

Collema subfurvum (Mull.

Arg.) Degel. [= C. subflaccidum

Degl.]; on post oak and red

cedar (Juniperus

virginiana); Creek,

Lincoln, Osage, and Payne

counties.

*Leptogium chloromelum (Sw.) Ny 1. [occurs rarely in midcontinental North America; L. millegranum Sierk is more common] is represented by Keck 614 on cedar, four miles northeast of Ripley in Payne County, and by Keck 796 on post oak, three miles south of Chandler in Lincoln county.

Leptogium cyanescens (Ach.) Khr. [(Rabenh.) Körber]; on post oak; Lincoln County.

\section{Heppiaceae}

*Heppia hassei Zahl. [= Peltula obscurans Nyl. var. hassei (Zahlbr.) Wetmore] is represented by Keck 1067 on limestone, six miles northwest of Renfrow in Grant County, and by Keck 78 and 268 from Osage and Garfield counties, respectively.

Pannariaceae

*Placynthium nigrum (Huds.)

S. Gray is represented by Keck 1075B on limestone, six miles northwest of Renfrow in Grant county, and by Keck 1081 on loosely compacted silty clay, 15 miles east of Kingfisher in Kingfisher County.

*Coccocarpia cronia Tuck. [= C. palmicola (Sprengel) Arv. \& D.J.
Oklahoma Native Plant Record Volume 6, Number 1, December 2006

Galloway]; on moss-covered sandstone; Creek County.

Peltigeraceae (31)

Peltigera canina (L.) Willd.; [probably $\boldsymbol{P}$. praetextata (Flörke ex Sommerf.) Zopf]; on shaded mossy banks, usually overlying sandstone; Creek, Pawnee, and Payne counties.

Lecideaceae

Lecidea decipens (Ehrh.) Ach. [= Psora decipiens (Hedw.) Hoffm.]; on open soil over Dermatocarpon hepaticum; Grant, Kingfisher, and Noble counties.

Lecidea rufonigra (Tuck.) Nyl. [= Psorula rufonigra (Tuck.) Gotth.

Schneid.] is represented by Keck 1010 on sandstone, one-half mile southwest of Tuskegee in Creek County.

Lecidea russellii Tuck . [= Psora russellii (Tuck.) A. Schneid., a terricolous species - these reports of saxicolous populations refer to Psora pseudorussellii Timdal]; on sandstone and limestone; Lincoln, Logan, and Osage counties.

*Lecidea tesselina Tuck. [= Lecanora oreinoides (Körber) Hertel \& Rambold] is represented by Keck 10 on sandstone, two miles east of Cleveland, in Osage County, and by Keck $113,143,871$, and 880 at other locations in Osage county.

*Bacidia granosa (Tuck.) Zahl . [= Bacidia coprodes (Körber) Lettau] is represented by Keck 75 on limestone, five miles west of Skiatook, in Osage county.

Keck, D.W. 
*Bacidia umbrina (Ach.) Bausch [= Scoliciosporum umbrinum) Ach.) Arnold] is represented by Keck 586 on sandstone, seven miles west of Perry in Noble County.

Cladoniaceae (16, 24) * Cladonia apodocarpa Robbins is represented by Keck 1053 on shaded soil, 12 miles north of Pawhuska in Osage County, and by Keck 1046, one mile west of Mounds in Creek County.

*Cladonia capitata (Michx.) Spreng . [= C. peziziformis (With.) J.R. Laundon] is represented by Keck 784 on shaded soil, five miles southwest of Stillwater in Payne County and by Keck 100, 663, 998, and 1037 in Osage, Pawnee, Logan, and Lincoln counties, respectively.

Cladonia chlorophaea (Fik.) Spreng. [possibly including or consisting of this species and/or $C$. cryptochlorophaea Asahina and C. grayi G. Merr.]; on thin soil over sandstone; Creek, Lincoln, Osage, Pawnee, and Payne counties.

*Cladonia fimbriata (L.) Fr. [possibly, but not known from Oklahoma; these reports more likely refer to the $C$. chlorophaea complex (see previous entry] is represented by Keck 388 on thin soil over sandstone, three miles south of Chandler in Lincoln County.

*Cladonia subcariosa Nyl. [= C. polycarpoides Nyl.] is represented by Keck 26 on shaded soil, two miles east of Cleveland, in Osage
County, and by Keck $392 \mathrm{C}$ and 663B in Lincoln and Pawnee counties, respectively.

\section{*Cladonia subtenuis (des} Abbayes) Evans [(Abbayes) Mattick] is represented by Keck 847 on slightly shaded soil, 12 miles north of Pawhuska in Osage County.

*Cladonia uncialis (L.) Web. [(L.) F.H.Wigg.] is represented by Keck 1054 on slightly shaded soil, 12 miles north of Pawhuska in Osage County.

Acarosporaceae

Sarcogyne clavus (Ram.)

Krmph. is represented by

Keck 29 on sandstone, two miles east of Cleveland, in Osage County, and by Keck $465,289,359,540,595$, and 674 in Creek, Garfield, Lincoln, Logan, Noble, and Pawnee counties, respectively.

* Sarcogyne pruinosa (Sm.)

Kbr. [=S. regularis Körber.] is represented by Keck 725 on sandstone, seven miles east of Fairfax in Osage county, and by Keck 271 and 1073 on limestone, in Garfield and Grant counties, respectively.

Sarcogyne simplex (Dav.) Nyl. [= Polysporina simplex Davies) Vězda]; on sandstone; Logan County.

Acarospora citrina (Tayl.) Zahl.; on sandstone; Creek, Garfield, Lincoln, Logan, Noble, Osage, Pawnee, and Payne counties. 
*Acarospora fuscata (Nyl.)

Arn. [(Schrader) Arnold] is

represented by Keck 82 on

limestone, five miles west

of Skiatook, and Keck 2 on

sandstone, two miles east

of Cleveland, both in Osage

County, and Keck 1033, 659,

and 642 in Lincoln, Pawnee,

and Payne counties

respectively.

*Acarospora smaragdula (Wh.)

Th. Fr. is represented by

Keck 40 on sandstone, two

miles east of Cleveland, in

Osage County, and by Keck

368 and 653 in Lincoln and

Pawnee counties,

respectively.

Pertusariaceae

*Pertusaria leioplaca

(Ach . ) DC. [DC.; this report may include or consist of $P$. paratuberculifera Dibben, which is locally common on hardwoods in the eastern portion of the study area] is represented by Keck 13 on blackjack oak, two miles east of Cleveland, in Osage County, and by Keck 464, 382, 573, and 611 on various woody species in Creek, Lincoln, Noble, and Payne counties, respectively.

Pertusaria multipuncta

(Turn.) Nyl.; [=P. multipunctoides Diben] on

blackjack oak, post oak, and hickory; Creek, Lincoln, Osage, and Payne counties.

Pertusaria pertusa (L.) Tuck . [North American reports of this taxon are based on misidentifications; several pre-1980 Missouri specimens determined as this species are actually $P$.
Oklahoma Native Plant Record Volume 6, Number 1, December 2006

plittiana Erichsen, and the sandstone substrate cited here indicates a similar possibility]; on sandstone; Creek and Payne counties.

*Pertusaria pustulata (Ach.) Duby is represented by Keck 415 on post oak, three and one-half miles east of Shamrock in Creek County, and by Keck 368, 128, 669, and 269 on various woody species in Lincoln, Osage, Pawnee, and Payne counties respectively.

*Pertusaria velata (Turn.)

Nyl. is represented by Keck 1028 on sandstone, one mile northwest of Ripley in Payne county .

Lecanoraceae

Lecanora atra (Huds.) Ach. [= Tephromela atra (Huds.) Hafellner]; on sandstone; Creek County.

* Lecanora calcarea (L.) Smrft. [=Aspicilia calcarea (L.) Mudd; local reports may include or consist of $A$. contorta (Hoffm.) Kremp.) is represented by Keck 66 on limestone, five miles west of Skiatook, in Osage County, and by Keck 270, $1070,531,558$, and 905 in Garfield, Grant, Logan, Noble, and Pawnee counties, respectively.

* Lecanora dispersa (Pers.)

Rohl . [= (Pers.) Sommerf.] is represented by Keck 240 on cement, three miles southwest of Hillsdale in Garfield County, and by Keck 538 , 582, and 728 on sandstone, in Logan, Noble, and Osage counties respectively.

Keck, D.W. 
Lecanora hageni Ach.; [= $L$. hagenii (Ach.) Ach.] on hickory, hackberry, persimmon, pecan (Carya illinoensis), red cedar, and various oaks; Creek, Kay, Lincoln, Noble, and Payne counties.

* Lecanora melaena (Hedl.) Fink is represented by Keck 38 on sandstone, two miles east of Cleveland, in Osage county.

\section{Lecanora muralis (Schreb.)} Rabh.; on sandstone and limestone; Creek, Garfield, Kay, Logan, Noble, Osage, Pawnee, and Payne counties.

* Lecanora piniperda Kbr. [Brodo et al. (2001) restrict the range of this taxon to boreal North America and the Rocky mountains] is represented by Keck 414 on post oak, three and onehalf miles southwest of Avery in Lincoln County, and by Keck 853 on redbud, 12 miles north of Pawhuska in Osage County.

*Lecanora rubina (Vill.) Ach . [= Rhizoplaca chrysoleuca (Sm.) Zopf] is represented by Keck 117 on sandstone, 12 miles north of Pawhuska in Osage County, and by Keck 948 and 686 in Noble and Pawnee counties, respectively.

Lecanora subfusca (L.) Ach. [= L. allophana Nyl., but probably refers to L. hybocarpa (Tuck.) Brodo]; on hackberry, persimmon, red oak, hickory, redbud, ash (Fraxinus americana), and red cedar; Creek, Kay, Lincoln, Osage, Pawnee, and Payne counties.
Lecanora varia (Ehrh.)

Ach . [(Hoffm.) Ach.; almost certainly refers to L. strobilina (Sprengel.) Keiffer]; on hickory, persimmon, post oak, plum (Prunus sp.), birch (Betula nigra), redbud, ash, and cedar; Creek, Kay, Lincoln, Osage, Pawnee, and Payne counties.

* Lecania californica (Zahl.) Fink is represented by Keck 71 on limestone, five miles west of Skiatook, in Osage County.

* Lecania perproxima

(Nyl.)zahl. is represented by Keck 1015 on sandstone, one-half mile west of Meridian in Logan County.

*Candelariella vitellina (Ehrh.) Mull Arg. [(Hoffm.) Müll. Arg.]; on sandstone; Creek, Garfield, Lincoln, Logan, Noble, Osage, Pawnee, and Payne counties.

\section{*Candelariella xanthostigma} (Pers.) Lett. [(Ach.) Lettau] is represented by Keck 188 over Physcia sp. on cottonwood, two miles south of Lamont in Grant County .

\section{Parmeliaceae}

Candelaria concolor (Dicks.) [(Dicks.) Stein.] Arn. Var. concolor; on elm, soapberry, (Sapindus drummondii), red cedar, hackberry, willow, birch, mulberry (Morus rubra), post oak, and blackjack oak; Creek, Garfield, Grant, Kingfisher, Logan, Noble, and Osage counties. 
*Candelaria concolor

(Dicks.) Arn. var. effuse (Tuck.) Merr. \& Burnh. is represented by Keck 982 on Willow, three miles southeast of Hillsdale in Garfield county, and by Keck 323 on elm and 899 on bois-d'Arc in Logan and Pawnee counties, respectively.

\section{Candelaria fibrosa (Fr.)}

Mull. Arg.; on most woody species and on sandstone; Creek, Garfield, Grant, Kay, Kingfisher, Lincoln, Logan, Noble, Osage,

Pawnee, and Payne counties.

Parmelia bolliana Mull.

Arg . ; [= Punctelia bolliana (Müll. Arg.) Krog and/or Punctelia graminicola (de Lesd.) Egan]; on most woody species and on sandstone; Creek, Garfield, Grant, Kay, Kingfisher, Lincoln, Logan, Noble, Osage,

Pawnee, and Payne counties.

Parmelia caperata (L.) Ach.; [= Flavoparmelia caperata (L.) Hale and/or F. baltimorensis (Gyeln. \& Forriss.)

Hale; blackjack oak, sandstone, and thin soil overlying sandstone; Creek, Lincoln, Osage, and Payne counties.

\section{Parmelia conspersa}

(Ehrh . ) Ach . [= Xanthoparmelia conspersa (Ach.) Hale; may refer to other isidiate taxa of Xanthoparmelia, with a dark lower cortex, such as $X$. mexicana (Gyeln.) Hale]; on sandstone; Creek and Osage counties.

*Parmelia haitiensis (Hale) [= Parmotrema hatiense (Hale) Hale] is represented by Keck 944 on sandstone, four miles
Oklahoma Native Plant Record Volume 6, Number 1, December 2006

northeast of Ripley in Payne County, and by Keck 418, 348, and 841 on post oak or black jack in Creek, Lincoln, and Osage counties, respectively.

\section{Parmelia isidiata (Anzi)}

Gyel.; on sandstone; Logan, Noble, and Pawnee counties.

Parmelia obsessa (Ach.); [= Myelochroa obsessa (Ach.) Elix \& Hale]; on sandstone; Creek County.

Parmelia reticulate (Tayl.)[= Parmotrema reticulatum (Taylor) $\mathbf{M}$. Choisy]; on blackjack oak, post oak, redbud, elm, red cedar, and sandstone; Creek, Kay, Kingfisher, Lincoln, Logan, Noble, Osage, Pawnee, and Payne counties.

Parmelia rudecta Ach. [Punctelia rudecta (Ach.) Krog; may also include Punctelia missouriensis G. Wilh. \& Ladd]; on blackjack oak and sandstone; Lincoln, Osage, and Payne counties.

Parmelia stenophylla (Achl.) Heug . [= Xanthoparmelia viriduloumbrina (Gyeln.) Lendemer]; on sandstone; Osage County.

\section{Caloplacaceae}

*Caloplaca arizonica Rudolph non Magn. [possibly C. subsoluta (Nyl.) Zahlbr.] is represented by Keck 94 on sandstone, two miles north of Barnsdall in Osage county, and by Keck 1007 and 813 in Logan and Pawnee counties, respectively.

\section{Caloplaca aurantiaca} (Lightf.) Th. Fr. [=C. flavorubescens (Huds.) J.R. Laundon]; on most woody species; Creek, Garfield, Grant, Kay,

Keck, D.W. 
Kingfisher, Lincoln, Logan, Noble, Osage, and Payne counties.

Caloplaca cerina (Ehrh.) Th. Fr.; on elm and cottonwood; Garfield and Grant counties.

*Caloplaca chrysophthalma Degel. [while this taxon is frequent in the region, it is a corticolous species] is represented by Keck 462, $748,835,689$, and 308 on various woody species in Creek, Kay, Osage, Pawnee, and Payne counties, respectively.

*Caloplaca dicipiens (Arn. ) Jatta. [(Arnold) Blomb. \& Forss.] is represented by Keck 583 and 597 on sandstone, seven miles west of Perry in Noble County.

*Caloplaca flavovirescens (Wulf.) D.T.\& S. is represented by Keck 4 on sandstone, two miles east of Cleveland, in Osage County, and by Keck 432, 1012, and 568 from Creek, Lincoln, and Noble counties, respectively.

\section{*Caloplaca lobulata} (Floerke) Hellb. [(Flörke) de Lesd.]is represented by Keck 92 on sandstone, two miles north of Barnsdall in Osage County, and by Keck 376, 527, and 814 from Lincoln, Logan, and Pawnee counties, respectively.

\section{*Caloplaca microphylina} (Tuck.) Hasse is represented by Keck 278 on mulberry, eight miles north of Garber in Garfield
County, and by Keck 220, 757, 510, 410, and 576, primarily on fence posts and dead wood, in Grant, Kay, Kingfisher, Lincoln, and Noble counties, respectively.

Caloplaca murorum (Hoffm.) Th. Fr. ; [= C. saxicola (Hoffm.) Nordin (may represent misidentification)] on sandstone and limestone; Garfield, Osage, and Payne counties.

*Caloplaca ulmorum Fink [(Fink)

Fink] is represented by Keck 233 on cottonwood, three miles southeast of Hillsdale in Garfield County, and by Keck 178, 746, 521, 417, and 155 on elm, cottonwood, and dead wood in Grant, Kay Kingfisher, Logan, and Osage counties, respectively.

Teloschistaceae (30)

Teloschistes chrysophthalmus

(L.) Th. Fr.; on various woody species especially dead twigs; Creek, Garfield, Grant, Kay, Kingfisher, Lincoln, Logan, Noble, Osage, Pawnee, and Payne counties.

\section{Xanthoria candelaria (L.)} Arn. [possibly Xanthomendoza fulva (Hoffm.) Søchting or Xanthomendoza fallax (Hepp) Søchting]; on various woody species, especially bark of dead trees; Creek, Garfield, Grant, Kay, Kingfisher, Lincoln, Logan, Noble, Osage, Pawnee, and Payne counties. 
Buelliaceae (22)

*Buellia alboatra (Hoffm.) Th. Fr. [= Diplotomma alboatrum (Hoffm.) Flotow, possibly including or consisting of $D$. venustum (Körber) Körber] is represented by Keck 1079 on limestone, six miles northwest of Renfrow in Grant county, and by Keck 1065 in Garfield County. Imshaug (22) lists this species as occurring in several northeastern and midwestern states extending no farther south than Colorado.

*Buellia novomexicana B. de Lesd. [= B. tyrolensis Körber] is represented by Keck 2 on sandstone, two miles east of Cleveland, in Osage County, and by Keck 593 on sandstone and 86 on limestone in Noble and Osage counties, respectively.

Buellia punctata (Hoffm.) Mass . [= Amandinea punctata (Hoffm.) Coppins \& Scheid.]; on sandstone and dead wood; Garfield, Grant, Osage, Pawnee, and Payne counties.

*Buellia retrovertens Tuck. is represented by Keck 581 on sandstone, seven miles west of Perry in Noble County, and by Keck 675 from Pawnee County. Imshaug (22) lists this species as occurring from Texas, New Mexico, and Colorado westward to the coast.

*Buellia schaereri Dnot. [may represent misidentifications; this is a boreal taxon that is restricted to coniferous substrates (possibly Amandinea sp.?)] is represented by Keck 509 and 513 on dead wood, one-half mile south of Loyal, in Kingfisher County. Imshaug (22) lists this species as boreal, and reported only from states bordering Canada.

\section{Buellia spuria (Schaer.)} Anzi; on sandstone; Osage County.

*Buellia stigmaea Tuck. [=B. maculate Bungartz?] Is represented by Keck 882 on sandstone, two miles east of Cleveland, in Osage County, and by Keck 439 and 711 in Creek County. Imshaug (22) lists this species from several southern states but not farther west than Missouri.

*Buellia vilis Th.Fr. is represented by Keck 67 on limestone, five miles west of Skiatook, in Osage County. Imshaug (22) lists this species only from North Dakota and Colorado.

\section{Rinodina oreina (Ach.) Mass.} [=Dimelaena oreina (Ach.) Norman]; on sandstone; Osage and Pawnee counties.

Physciaceae (23)

*Pyxine caesiopruinosa (Tuck.) Imshaug [possibly $P$. subcinerea Stirton] is represented by Keck 702 on red oak, five miles southeast of Oilton, in Creek County. Imshaug (23) lists this species as occurring only from several Gulf Coast states.

Keck, D.W. 
Physcia aipolia (Ehrh.) Hampe [(Ehrh. Ex Humb.) Fürnr.]; on various woody species; Garfield, Grant, Kay, Kingfisher, Lincoln, Logan, Noble, Osage, Pawnee, and Payne counties.

Physcia ciliata (Hoffm.) DR . [= Phaeophyscia ciliata (Hoffm.) Moberg]; on soapberry, elm, cottonwood, post oak, and ash; Garfield, Grant, Kay, Lincoln, Noble, Osage, Pawnee, and Payne counties.

Physcia elaeina (Sm.) A. I. Sm . [= Hyperphyscia adglutinata (Flörke) H. Mayrhofer \& Poelt] ; on cottonwood and hickory; Garfield, Grant, and Osage counties

Physcia grisea (Lam.) Zahl. [probably Physconia leucoleiptes (Tuck.) Essl.]; on blackjack oak, post oak, hickory, and elm; Creek, Lincoln, Noble, and Osage counties.

*Physcia halei Thomson is represented by Keck 816 on sandstone, eight miles north of Morrison, in Pawnee County, and by Keck 115, 134, and 875 from Osage County.

Physcia millegrana Degel.; on birch; Osage County.

Physcia orbicularis (Neck.) Poetsch. [= Phaeophyscia orbicularis (Necker) Moberg, but probably other sorediate species including $P$. adiastola (Essl.) Essl, P. insignis ) Mereschk.) Moberg, P. pusilloides (Zahlbr.) Essl. or P. rubropulchra (Degel.) Essl.]; on various woody species and limestone; Creek, Garfield, Kay, Kingfisher, Logan,
Noble, Osage, and Payne counties.

Physcia stellaris (L.) Nyl.; on various woody species and sandstone; Creek, Garfield, Kay, Kingfisher, Lincoln, Logan, Noble, Osage, Pawnee, and Payne counties.

*Physcia syncolla Tuck. [= Hyperphyscia syncolla (Tuck ex Nyl.) Kalb]

is represented by Keck 1041

on hackberry, one mile west

of Mounds in Creek County, and by Keck 197, 737, 480, $383,319,556,156,645$, and 635 on various woody species from Garfield, Grant, Kay, Kingfisher, Lincoln, Logan, Noble, Osage, Pawnee, and Payne counties, respectively.

Physcia teretiuscula (Ach.) Lynge [= P. dubia (Hoffm.) Lettau; possibly Speerschneidera euploca (Tuck.) Trevisan or Physcia subtilis Degel.]; on sandstone; Creek County.

Physcia tribacoides Nyl.; [possibly $\boldsymbol{P}$. americana G. Merr.] on post oak, blackjack oak, elm, hackberry, persimmon, red cedar, and sandstone; Creek, Grant, Kay, Lincoln, Logan, Osage, and Payne counties.

Anaptychia granulifera (Ach.) Mass . ; [= Heterodermia granulifera (Ach.) W.L. Culb.] on post oak; Osage County.

Anaptychia heterochroa Vain. [= Heterodermia obscurata (Nyl.) Trevisan];

on various oaks, hickory, and sandstone; Creek, Lincoln, Osage, Pawnee, and Payne counties. 


\section{Anaptychia hypoleuca (Muhl.)} Vain. [= Heterodermia hypoleuca (Muhl.) trevisan]; on post oak and red oak; Creek and Osage counties.

\section{Anaptychia speciosa (Wulf.)} Mass . [= Heterodermia speciosa (Wulfen) Trevisan]; on sandstone; Payne County.

\section{Iichenes Imperfecti}

Leprariaceae

* Lepraria chlorina Ach. [= Chrysothrix chlorina (Ach.) J.R. Laundon, but probably Chrysothrix candelaris (L.) J.R. Laundon] is represented by Keck 1052 on birch, in Osage Hills state Park in Osage County.

\section{*Crocynia membranacea}

(Dicks.) Zahl. [probably

\section{Lepraria lobificans Nyl.] is}

represented by Keck 307 on post oak, one mile north of Coyle in Payne county, and by Keck 422, 353, 315, 562, and 140 on various oaks or sandstones from Creek, Lincoln, Logan, Noble, and Osage counties, respectively.

\section{SELECTED BIBLIOGRAPHY}

*General works not cited in text

1. Asahina, Y. 1954. Chemistry of Lichen Substances. Tokyo.

2. Berry, E. C. 1941. A

Monograph of the Genus Parmelia in

North America, North of Mexico

Ann. Mo. Bot. Gard.

$28: 31-146$.

3. Bruner, W. E. 1931. The

Vegetation of Oklahoma.

Ecological Monographs.

$1: 100-188$.
Oklahoma Native Plant Record Volume 6, Number 1, December 2006

*4. Culberson, William L. 1955. A Guide to the Literature on the Lichen Flora and Vegetation of the United States. U.S.D.A. Agri. Res. Service. Plant Disease Epidemics and Identification section. Beltsville, MD. Special Publication 7:1-54.

5. Degelius, Gunnar. 1954. The Lichen Genus Collema in Europe.

Symb. Bot. Upsal. 12 (2) : 1-499.

6. Evans, A. W. 1930. The Cladoniae of Connecticut. Trans. Conn. Acad. Arts and Sciences. 30:357-510.

7. Fearing, O. S. 1952.

Preliminary Study of the Taxonomy and Ecology of Kansas Lichens. Univ .

Kans. Sci. Bull. 35:543575.

8. Fink, Bruce. 1911. The Nature and Classification of Lichens-I. Views and Arguments of Botanists Concerning Classification. Mycologia. $3: 231-269$.

9. Fink, Bruce. 1913. The Nature and Classification of Lichens-II. The Lichen and Its Algal Host. Mycologia. 5:97-166.

10. Fink, Bruce. 1935. The Lichen flora of the United States. Univ. of Mich. Press, Ann Arbor.

11. Hale, Mason E., Jr. 1952. Studies on the Lichen Rinodina Oreina in North America. Bull. Tor. Bot. Cl. 79:251-259.

12. Hale, Mason E., Jr. 1955. Xanthoparmelia in North America I. The Parmelia Conspersa-Stenophylla group. Bull. Tor. Bot. Cl. $82: 9-21$.

13. Hale, Mason E., Jr. and William L. Culberson. 1956. A Checklist of the Lichens of the United States, Canada, and Alaska. Castenea. 21:73-105.

Keck, D.W. 
14. Hale, Mason E, Jr. 1956. Chemical Strains of the Parmelia Conspersa-Stenophylla Group in South Central United States. Bull . Tor. Bot. Cl . 83:218220.

15. Hale, Mason E., Jr. 1956. A Note on Lichenes Americani Exsiccati, fascicle $I$. The Bryologist. 59:41-43.

16. Hale, Mason E., Jr. 1957. Corticolous Lichen Flora of the Ozark Mountains. Trans. Kans. Acad. Sci. 60:155-160.

17. Hale, Mason E., Jr. 1957. Lichen Handbook. Smithsonian Institution Washington, D. C.

18. Hale, Mason E., Jr. 1958. The Status of Usnea Diplotypus in North America. The Bryologist. 61:247-248.

19. Hale, Mason E., Jr. 1959. New or Interesting Species of Parmelia in North America. The Bryologist. 62:20-21.

20. Hedrick, Joyce. 1930. Lichens from the State of Oklahoma. Papers Mich. Acad. Sci., Arts, and Letters. 12:101-110.

21. Howard, Grace E. 1950. Lichens of the State of $W$ ashington. Univ. of Wash. Press, Seattle.

22. Imshaug, H. A. 1951. The Lichen-forming Species of the Genus Buellia in the United States and Canada. Univ. Microfilms Publ. 2607, Ann Arbor, Michigan.

23. Imshaug, H. A. 1957. The Lichen Genus Pyxine in North and Middle America. Trans. Amer. Micros. Soc. 76:246269 .
24. Luttrell, E. S. 1954. The Cladoniaceae of Virginia. Lloydia. $17: 275-306$.

25. Nearing, G. G. 1947. The Lichen Book. Published by the author, Ridgewood, New Jersey.

26. Oosting, H.J. and L. E. Anderson. 1937. The Vegetation of a Barefaced Cliff in Western North Carolina. Ecology . 18:280292 .

27. Schneider, Albert. 1897. A Text-Book of General Lichenology. Wm. N. Clute and Company, Binghamton.

28. Smith, Annie L. 1921. Lichens. Cambridge Univ. Press, Cambridge.

29. Snyder, L.C. 1917. Geography of Oklahoma. Okla. Geol. Survey. Bull. 27:1-325.

30. Thomson, John W., Jr. 1949. The Teloschistaceae of WisconsinPapers on Wisconsin Lichens III. Amer. Midl. Nat. 41:1-68.

31. Thomson, John W., Jr. 1950. The Species of Peltigera of North America, North of Mexico. Amer. Midl. Nat. 44:1-68.

32. United States Department of Agriculture. 1941. Yearbook of Agriculture. Climate and Man. (Washington, D. C.) Gov't. Printing Office: 1165-1174.

33. Weaver, John E. and Frederick E. Clements. 1938. Plant Ecology. McGrawHill Book Co., New York: 66-68.

34. Wolfe, John N. 1940. A Catalog of the Lichens of Ohio. Ohio Biol. Sur. Bull. 36:1-50.

*35. Zahlbruckner, A. 192240. Catalogus Lichenus Universalis. Leipzig. 10 vol. 
TABLE I SPECIES OCCURRENCY BY COUNTIES

\begin{tabular}{|c|c|c|c|c|c|c|c|c|c|c|c|}
\hline & 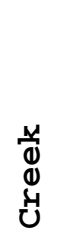 & 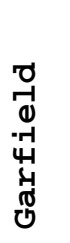 & $\begin{array}{l}\text { 若 } \\
\text { 品 }\end{array}$ & त्ञ & 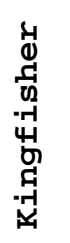 & 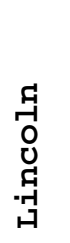 & 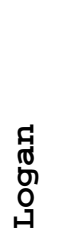 & $\begin{array}{l}0 \\
0 \\
0 \\
0 \\
z \\
z\end{array}$ & $\begin{array}{l}0 \\
0 \\
0 \\
0 \\
0\end{array}$ & 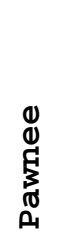 & 离 \\
\hline $\begin{array}{l}\text { Acarospora } \\
\text { citrine }\end{array}$ & $\mathrm{X}$ & $\mathrm{X}$ & & & & $\mathrm{X}$ & $\mathrm{X}$ & $\mathrm{X}$ & $\mathrm{X}$ & $\mathrm{X}$ & $\mathrm{X}$ \\
\hline A. fuscata & & $\mathrm{X}$ & & & & $\mathrm{X}$ & & & $\mathrm{X}$ & $\mathrm{X}$ & $\mathrm{X}$ \\
\hline A.smaragdula & & & & & & $\mathrm{X}$ & & & $\mathrm{X}$ & $\mathrm{X}$ & \\
\hline $\begin{array}{l}\text { Allarthonia } \\
\text { caesia }\end{array}$ & $\mathrm{X}$ & & & & & & & & $\mathrm{X}$ & & \\
\hline $\begin{array}{l}\text { Anaptychia } \\
\text { granulifera }\end{array}$ & & & & & & & & & $\mathrm{X}$ & & \\
\hline A. heterochroa & $\mathrm{X}$ & & & & & $\mathrm{X}$ & & & $\mathrm{X}$ & $\mathrm{X}$ & $\mathrm{X}$ \\
\hline A. hypoleuca & $\mathrm{X}$ & & & & & & & & & $\mathrm{X}$ & \\
\hline A. speciosa & & & & & & & & & & & $\mathrm{X}$ \\
\hline Bacidia granosa & & & & & & & & & $\mathrm{X}$ & & \\
\hline B. umbrina & & & & & & & & $\mathrm{X}$ & & & \\
\hline $\begin{array}{l}\text { Buellia } \\
\text { alboatra }\end{array}$ & & $\mathrm{x}$ & $\mathrm{X}$ & & & & & & & & \\
\hline B. novomexicana & & & & & & & & $\mathrm{X}$ & $\mathrm{X}$ & $\mathrm{X}$ & \\
\hline B. punctata & & $\mathrm{X}$ & $\mathrm{X}$ & & & & & & $\mathrm{X}$ & $\mathrm{X}$ & $\mathrm{X}$ \\
\hline B. retrovertens & & & & & & & & $\mathrm{X}$ & & $\mathrm{X}$ & \\
\hline B. schaereri & & & & & $\mathrm{X}$ & & & & & & \\
\hline B. spuria & & & & & & & & & $\mathrm{X}$ & & \\
\hline B. stigmaea & $\mathrm{X}$ & $-\sigma_{1}$ & 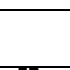 & $\pi$ & 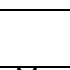 & 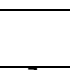 & 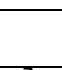 & 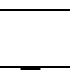 & $\mathrm{X}$ & - & 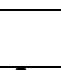 \\
\hline
\end{tabular}

Keck, D.W. 


\begin{tabular}{|c|c|c|c|c|c|c|c|c|c|c|c|}
\hline B. vilis & & & & & & & & & $\mathrm{X}$ & & \\
\hline $\begin{array}{l}\text { Caloplaca } \\
\text { arizonica }\end{array}$ & & & & & & & $\mathrm{X}$ & & $\mathrm{X}$ & $\mathrm{X}$ & \\
\hline C. aurantiaca & $\mathrm{X}$ & $\mathrm{X}$ & $\mathrm{X}$ & $\mathrm{X}$ & $\mathrm{X}$ & $\mathrm{X}$ & $\mathrm{X}$ & $\mathrm{X}$ & $\mathrm{X}$ & & $\mathrm{X}$ \\
\hline C. cerina & & $\mathrm{X}$ & $\mathrm{X}$ & & & & & & & & \\
\hline $\begin{array}{l}\text { C. } \\
\text { chrysophthalma }\end{array}$ & $\mathrm{X}$ & & & $\mathrm{X}$ & & $\mathrm{X}$ & & & $\mathrm{X}$ & $\mathrm{X}$ & $\mathrm{X}$ \\
\hline C. decipiens & & & & & & & & $\mathrm{X}$ & & & \\
\hline $\begin{array}{l}C . \\
\text { flavovirescens }\end{array}$ & $\mathrm{X}$ & & & & & $\mathrm{X}$ & & $\mathrm{X}$ & $\mathrm{X}$ & & \\
\hline C. Iobulata & & & & & & $\mathrm{X}$ & $\mathrm{X}$ & & $\mathrm{X}$ & $\mathrm{X}$ & \\
\hline C. microphylina & & $\mathrm{X}$ & $\mathrm{X}$ & $\mathrm{X}$ & $\mathrm{X}$ & $\mathrm{X}$ & & $\mathrm{X}$ & & & \\
\hline C. murorum & & $\mathrm{X}$ & & & & & & & $\mathrm{X}$ & & $\mathrm{X}$ \\
\hline C. ulmorum & & $\mathrm{X}$ & $\mathrm{X}$ & $\mathrm{X}$ & $\mathrm{X}$ & & $\mathrm{X}$ & & $\mathrm{X}$ & & \\
\hline $\begin{array}{l}\text { Candelaria } \\
\text { concolor var. } \\
\text { concolor }\end{array}$ & $\mathrm{X}$ & $\mathrm{X}$ & $\mathrm{X}$ & & $\mathrm{x}$ & & $\mathrm{X}$ & $\mathrm{X}$ & $\mathrm{x}$ & & \\
\hline $\begin{array}{l}\text { C. concolor } \\
\text { var. effusa }\end{array}$ & & $\mathrm{X}$ & & & & & $\mathrm{X}$ & & & $\mathrm{X}$ & \\
\hline C. fibrosa & $\mathrm{X}$ & $\mathrm{X}$ & $\mathrm{X}$ & $\mathrm{X}$ & $\mathrm{X}$ & $\mathrm{X}$ & $\mathrm{X}$ & $\mathrm{X}$ & $\mathrm{X}$ & $\mathrm{X}$ & $\mathrm{X}$ \\
\hline $\begin{array}{l}\text { Candelariella } \\
\text { vitellina }\end{array}$ & $\mathrm{X}$ & $\mathrm{X}$ & & & & $\mathrm{X}$ & $\mathrm{X}$ & $\mathrm{X}$ & $\mathrm{x}$ & & $\mathrm{X}$ \\
\hline C. xanthostigma & & & $\mathrm{X}$ & & & & & & & & \\
\hline $\begin{array}{l}\text { Cladonia } \\
\text { apodocarpa }\end{array}$ & $\mathrm{X}$ & & & & & & & & $\mathrm{x}$ & & \\
\hline & 0 & 0 & 0 & 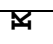 & $\$$ & F & H & $\mathbf{Z}$ & 0 & M & 0 \\
\hline
\end{tabular}

Keck, D.W. 


\begin{tabular}{|c|c|c|c|c|c|c|c|c|c|c|c|}
\hline C. capitata & & & & & & $\mathrm{X}$ & $\mathrm{X}$ & & $\mathrm{X}$ & $\mathrm{X}$ & $\mathrm{X}$ \\
\hline C. chlorophaea & $\mathrm{X}$ & & & & & $\mathrm{X}$ & & & $\mathrm{X}$ & $\mathrm{X}$ & $\mathrm{X}$ \\
\hline C. fimbriata & & & & & & $\mathrm{X}$ & & & & & \\
\hline C. subcariosa & & & & & & $\mathrm{X}$ & & & $\mathrm{X}$ & $\mathrm{X}$ & \\
\hline C. subtenuis & & & & & & & & & $\mathrm{X}$ & & \\
\hline C. uncialis & & & & & & & & & $\mathrm{X}$ & & \\
\hline $\begin{array}{l}\text { Coccocarpia } \\
\text { cronia }\end{array}$ & $\mathrm{X}$ & & & & & & & & & & \\
\hline $\begin{array}{l}\text { Collema } \\
\text { conglomeratum }\end{array}$ & & & & & & $\mathrm{X}$ & & & $\mathrm{X}$ & $\mathrm{X}$ & $\mathrm{X}$ \\
\hline C. subfurvum & $\mathrm{X}$ & & & & & $\mathrm{X}$ & & & $\mathrm{X}$ & & $\mathrm{X}$ \\
\hline $\begin{array}{l}\text { Crocynia } \\
\text { membranacea }\end{array}$ & $\mathrm{X}$ & & & & & $\mathrm{X}$ & $\mathrm{X}$ & $\mathrm{X}$ & $\mathrm{X}$ & & $\mathrm{x}$ \\
\hline $\begin{array}{l}\text { Dermatocarpon } \\
\text { hepaticum }\end{array}$ & & & $\mathrm{X}$ & & $\mathrm{X}$ & & & $\mathrm{X}$ & & & \\
\hline D. miniatum & & & & $\mathrm{X}$ & & & & & $\mathrm{X}$ & & \\
\hline D. tuckermani & & & & & & & & & $\mathrm{X}$ & & \\
\hline $\begin{array}{l}\text { Diploschistes } \\
\text { actinostomus }\end{array}$ & $\mathrm{X}$ & $\mathrm{X}$ & & & & $\mathrm{X}$ & $\mathrm{X}$ & $\mathrm{X}$ & $\mathrm{X}$ & $\mathrm{X}$ & \\
\hline $\begin{array}{l}D \cdot \text { scruposus } \\
\text { var. scruposus }\end{array}$ & & & & & & $\mathrm{X}$ & $\mathrm{X}$ & & $\mathrm{X}$ & & $\mathrm{x}$ \\
\hline $\begin{array}{l}\text { D. scruposus } \\
\text { var. bryophila }\end{array}$ & & & & & & $\mathrm{X}$ & & & & & $\mathrm{X}$ \\
\hline $\begin{array}{l}\text { Endocarpon } \\
\text { pusillum }\end{array}$ & & & & $\mathrm{X}$ & & $\mathrm{X}$ & & & & & \\
\hline Graphis scripta & & & & & & & & & & $\mathrm{X}$ & $\mathrm{X}$ \\
\hline & 0 & 0 & 0 & 4 & 4 & $\boldsymbol{H}$ & H & $\mathbf{z}$ & 0 & ه & M \\
\hline
\end{tabular}

Keck, D.W. 


\begin{tabular}{|l|l|l|l|l|l|l|l|l|l|l|l|}
\hline & & & & & & & & & & & \\
\hline Heppia hassei & & $\mathrm{X}$ & $\mathrm{X}$ & & & & & & $\mathrm{X}$ & & \\
\hline $\begin{array}{l}\text { Lecania } \\
\text { Californica }\end{array}$ & & & & & & & & & & & \\
\hline L. perproxima & & & & & & & $\mathrm{X}$ & & & & \\
\hline Lecanora atra & $\mathrm{X}$ & & & & & & & & & & \\
\hline L. calcarea & & $\mathrm{X}$ & $\mathrm{X}$ & $\mathrm{X}$ & & & $\mathrm{X}$ & $\mathrm{X}$ & $\mathrm{X}$ & $\mathrm{X}$ & \\
\hline L. dispersa & & $\mathrm{X}$ & & & & & $\mathrm{X}$ & $\mathrm{X}$ & $\mathrm{X}$ & $\mathrm{X}$ & \\
\hline L. hageni & $\mathrm{X}$ & & & $\mathrm{X}$ & & $\mathrm{X}$ & & $\mathrm{X}$ & & & $\mathrm{X}$ \\
\hline L. melaena & & & & & & & & & $\mathrm{X}$ & & \\
\hline L. muralis & $\mathrm{X}$ & $\mathrm{X}$ & & $\mathrm{X}$ & & & $\mathrm{X}$ & $\mathrm{X}$ & $\mathrm{X}$ & $\mathrm{X}$ & $\mathrm{X}$ \\
\hline L. piniperda & $\mathrm{X}$ & & & & & & & & $\mathrm{X}$ & & \\
\hline L. rubina & & & & & & & & $\mathrm{X}$ & $\mathrm{X}$ & $\mathrm{X}$ & \\
\hline L. subfusca & $\mathrm{X}$ & & & & & $\mathrm{X}$ & & & $\mathrm{X}$ & & $\mathrm{X}$ \\
\hline $\begin{array}{l}\text { Lecidea Varia } \\
\text { decipiens }\end{array}$ & $\mathrm{X}$ & & & $\mathrm{X}$ & & $\mathrm{X}$ & & & $\mathrm{X}$ & $\mathrm{X}$ & $\mathrm{X}$ \\
\hline L. rufonigra & $\mathrm{X}$ & & & & & & $\mathrm{X}$ & & & & \\
\hline L. russellii & & & & & & $\mathrm{X}$ & $\mathrm{X}$ & & $\mathrm{X}$ & & \\
\hline L. tesselina & & & & & & & & & $\mathrm{X}$ & & \\
\hline
\end{tabular}

Keck, D.W. 


\begin{tabular}{|c|c|c|c|c|c|c|c|c|c|c|c|}
\hline & 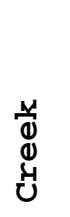 & 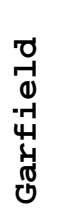 & $\begin{array}{l}\text { 䓪 } \\
\text { 岁 } \\
0\end{array}$ & $\underset{\mathbb{\pi}}{\vec{\pi}}$ & 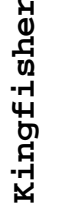 & 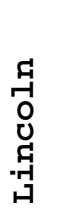 & $\begin{array}{l}\text { 员 } \\
\text { on } \\
\stackrel{1}{1}\end{array}$ & $\begin{array}{l}0 \\
\frac{\pi}{9} \\
0 \\
0 \\
0\end{array}$ & $\begin{array}{l}0 \\
0 \\
0 \\
0 \\
0 \\
0\end{array}$ & 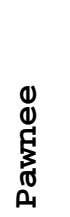 & $\coprod_{\substack{0 \\
\text { âd }}}^{0}$ \\
\hline $\begin{array}{l}\text { Lepraria } \\
\text { chlorine }\end{array}$ & & & & & & & & & $\mathrm{X}$ & & \\
\hline $\begin{array}{l}\text { Leptogium } \\
\text { chloromelum }\end{array}$ & & & & & & $\mathrm{X}$ & & & & & $\mathrm{X}$ \\
\hline L. cyanescens & & & & & & $\mathrm{X}$ & & & & & \\
\hline $\begin{array}{l}\text { Parmelia } \\
\text { bolliana }\end{array}$ & $\mathrm{X}$ & $\mathrm{X}$ & $\mathrm{X}$ & $\mathrm{X}$ & $\mathrm{X}$ & $\mathrm{X}$ & $\mathrm{X}$ & $\mathrm{X}$ & $\mathrm{X}$ & $\mathrm{X}$ & $\mathrm{x}$ \\
\hline P. caperata & $\mathrm{X}$ & & & & & $\mathrm{X}$ & & & $\mathrm{X}$ & & $\mathrm{X}$ \\
\hline P. conspersa & $\mathrm{X}$ & & & & & & & & $\mathrm{X}$ & & \\
\hline P. haitiensis & $\mathrm{X}$ & & & & & $\mathrm{X}$ & & & $\mathrm{X}$ & & $\mathrm{X}$ \\
\hline P. isidiata & & & & & & & $\mathrm{X}$ & $\mathrm{X}$ & & $\mathrm{X}$ & \\
\hline P. obsessa & & & & & & & & & $\mathrm{X}$ & & \\
\hline P. reticulata & $\mathrm{X}$ & & & $\mathrm{X}$ & $\mathrm{X}$ & $\mathrm{X}$ & $\mathrm{X}$ & $\mathrm{X}$ & $\mathrm{X}$ & $\mathrm{X}$ & $\mathrm{X}$ \\
\hline P. rudecta & & & & & & $\mathrm{X}$ & & & $\mathrm{X}$ & & $\mathrm{X}$ \\
\hline P. stenophylla & & & & & & & & & $\mathrm{X}$ & & \\
\hline $\begin{array}{l}\text { Peltigera } \\
\text { canine }\end{array}$ & $\mathrm{X}$ & & & & & & & & & $\mathrm{X}$ & $\mathrm{X}$ \\
\hline $\begin{array}{l}\text { Pertusaria } \\
\text { leioplaca }\end{array}$ & $\mathrm{X}$ & & & & & $\mathrm{X}$ & & $\mathrm{X}$ & $\mathrm{X}$ & $\mathrm{X}$ & $\mathrm{X}$ \\
\hline P. multipuncta & $\mathrm{X}$ & & & & & $\mathrm{X}$ & & & $\mathrm{X}$ & & $\mathrm{X}$ \\
\hline P. pertusa & $\mathrm{X}$ & & & & & & & & & & $\mathrm{X}$ \\
\hline P. pustulata & $\mathrm{X}$ & & & & & $\mathrm{X}$ & & & $\mathrm{X}$ & $\mathrm{X}$ & $\mathrm{X}$ \\
\hline P. velata & & & & & & & & & & & $\mathrm{x}$ \\
\hline & 0 & 0 & 0 & 4 & 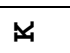 & H & H & $\mathbf{z}$ & 0 & a & a \\
\hline
\end{tabular}

Keck, D.W. 


\begin{tabular}{|c|c|c|c|c|c|c|c|c|c|c|c|}
\hline Physcia aipolia & & $\mathrm{X}$ & $\mathrm{X}$ & $\mathrm{X}$ & $\mathrm{X}$ & $\mathrm{X}$ & $\mathrm{X}$ & $\mathrm{X}$ & $\mathrm{X}$ & $\mathrm{X}$ & $\mathrm{X}$ \\
\hline P. ciliata & & $\mathrm{X}$ & $\mathrm{X}$ & $\mathrm{X}$ & & $\mathrm{X}$ & & $\mathrm{X}$ & $\mathrm{x}$ & $\mathrm{x}$ & $\mathrm{X}$ \\
\hline P. elaeina & & $\mathrm{X}$ & $\mathrm{X}$ & & & & & & $\mathrm{x}$ & & \\
\hline P. grisea & $\mathrm{X}$ & & & & & $\mathrm{X}$ & & $\mathrm{X}$ & $\mathrm{X}$ & & \\
\hline P. halei & & & & & & & & & $\mathrm{X}$ & $\mathrm{x}$ & \\
\hline P. millegrana & & & & & & & & & $\mathrm{X}$ & & \\
\hline P. orbicularis & $\mathrm{X}$ & $\mathrm{x}$ & & $\mathrm{X}$ & $\mathrm{X}$ & & $\mathrm{X}$ & $\mathrm{X}$ & $\mathrm{X}$ & & $\mathrm{X}$ \\
\hline P. stellaris & $\mathrm{X}$ & $\mathrm{X}$ & & $\mathrm{X}$ & $\mathrm{X}$ & $\mathrm{X}$ & $\mathrm{X}$ & $\mathrm{X}$ & $\mathrm{X}$ & $\mathrm{X}$ & $\mathrm{X}$ \\
\hline P. subtilis & & & & & & & & & $\mathrm{X}$ & $\mathrm{x}$ & \\
\hline P. syncolla & $\mathrm{X}$ & $\mathrm{x}$ & $\mathrm{x}$ & $\mathrm{X}$ & $\mathrm{X}$ & $\mathrm{X}$ & $\mathrm{X}$ & $\mathrm{x}$ & $\mathrm{x}$ & $\mathrm{x}$ & $\mathrm{x}$ \\
\hline P. teretiuscula & & & & & & & & & & $\mathrm{X}$ & \\
\hline P. tribacoides & $\mathrm{X}$ & & $\mathrm{X}$ & $\mathrm{X}$ & & $\mathrm{X}$ & $\mathrm{X}$ & & $\mathrm{X}$ & & $\mathrm{X}$ \\
\hline $\begin{array}{l}\text { Placynthium } \\
\text { nigrum }\end{array}$ & & & $\mathrm{X}$ & & $\mathrm{X}$ & & $\mathrm{X}$ & & & & \\
\hline $\begin{array}{l}\text { Pyxine } \\
\text { caesiopruinosa }\end{array}$ & $\mathrm{X}$ & & & & & & & & & & \\
\hline Rinodina oreina & & & & & & & & & $\mathrm{X}$ & $\mathrm{X}$ & \\
\hline $\begin{array}{l}\text { Sarcogyne } \\
\text { clavus }\end{array}$ & $\mathrm{X}$ & $\mathrm{X}$ & & & & $\mathrm{X}$ & $\mathrm{X}$ & $\mathrm{x}$ & $\mathrm{X}$ & $\mathrm{x}$ & \\
\hline \multirow[t]{2}{*}{ S. pruinosa } & & $\mathrm{X}$ & $\mathrm{X}$ & & & & & & $\mathrm{X}$ & & \\
\hline & 今 & J్ & 总 & 焉 & 获 & 哥 & $\begin{array}{l}\text { ட) } \\
\end{array}$ & $\begin{array}{l}\stackrel{0}{\circ} \\
\text { z }\end{array}$ & $\begin{array}{l}\text { on } \\
\text { on }\end{array}$ & $\underset{\alpha}{z}$ & 夏 \\
\hline
\end{tabular}

Keck, D.W. 


\begin{tabular}{|l|l|l|l|l|l|l|l|l|l|l|l|}
\hline & & & & & & & & & & & \\
\hline $\begin{array}{l}\text { S. Simplex } \\
\text { Staurothele } \\
\text { diffractella }\end{array}$ & & & & & $\mathrm{X}$ & & & & & & \\
\hline $\begin{array}{l}\text { S. umbrina } \\
\text { Teloschistes } \\
\text { Chrysophthalmus }\end{array}$ & $\mathrm{X}$ & $\mathrm{X}$ & $\mathrm{X}$ & $\mathrm{X}$ & $\mathrm{X}$ & $\mathrm{X}$ & $\mathrm{X}$ & $\mathrm{X}$ & $\mathrm{X}$ & $\mathrm{X}$ & $\mathrm{X}$ \\
\hline $\begin{array}{l}\text { Verrucaria } \\
\text { calsiceda }\end{array}$ & & & & & & & & & $\mathrm{X}$ & & \\
\hline $\begin{array}{l}\text { V. nigrescens } \\
\text { Xanthoria } \\
\text { candelaria }\end{array}$ & $\mathrm{X}$ & $\mathrm{X}$ & $\mathrm{X}$ & $\mathrm{X}$ & $\mathrm{X}$ & $\mathrm{X}$ & $\mathrm{X}$ & $\mathrm{X}$ & $\mathrm{X}$ & $\mathrm{X}$ & $\mathrm{X}$ \\
\hline \begin{tabular}{l} 
Total species \\
\hline
\end{tabular} & 44 & 29 & 24 & 21 & 19 & 45 & 32 & 33 & 77 & 41 & 42 \\
\hline
\end{tabular}

Keck, D.W. 
TABLE II TABULAR VIEW OF THE FAMILIES

\section{Families}

Verrucariaceae Dermatocarpaceae Arthoniaceae Graphidaceae Diploschistaceae Collemaceae Heppiaceae

Pannariaceae Peltigeraceae Lecideaceae Cladoniaceae Acarosporaceae Pertusariaceae Lecanoraceae Parmeliaceae Caloplacaceae Teloschistaceae Buelliaceae Physciaceae Leprariaceae TOTALS

\section{Genera}

2

2

1

1

1

2

1

2

1

2

1

2

1

3

2

1

2

2

3

2

$20 \quad 34$
Species and subordinate taxa

4

4

1

1

3

4

1

2

1

6

7

6

5

14

12

10

2

9

17

2

111

Keck, D.W. 


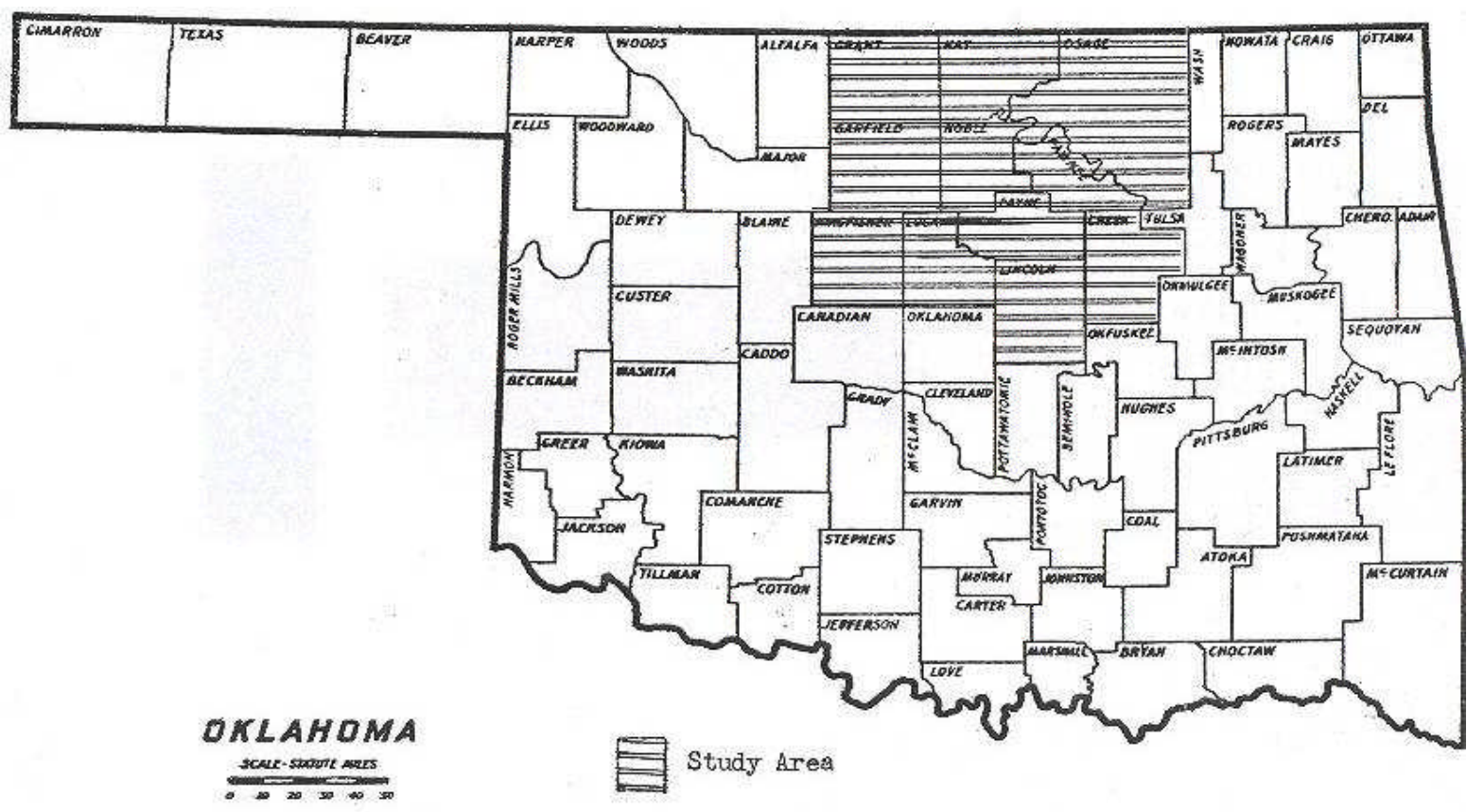

Fig. 1. Hap of Oklshoma Showing the Study Area

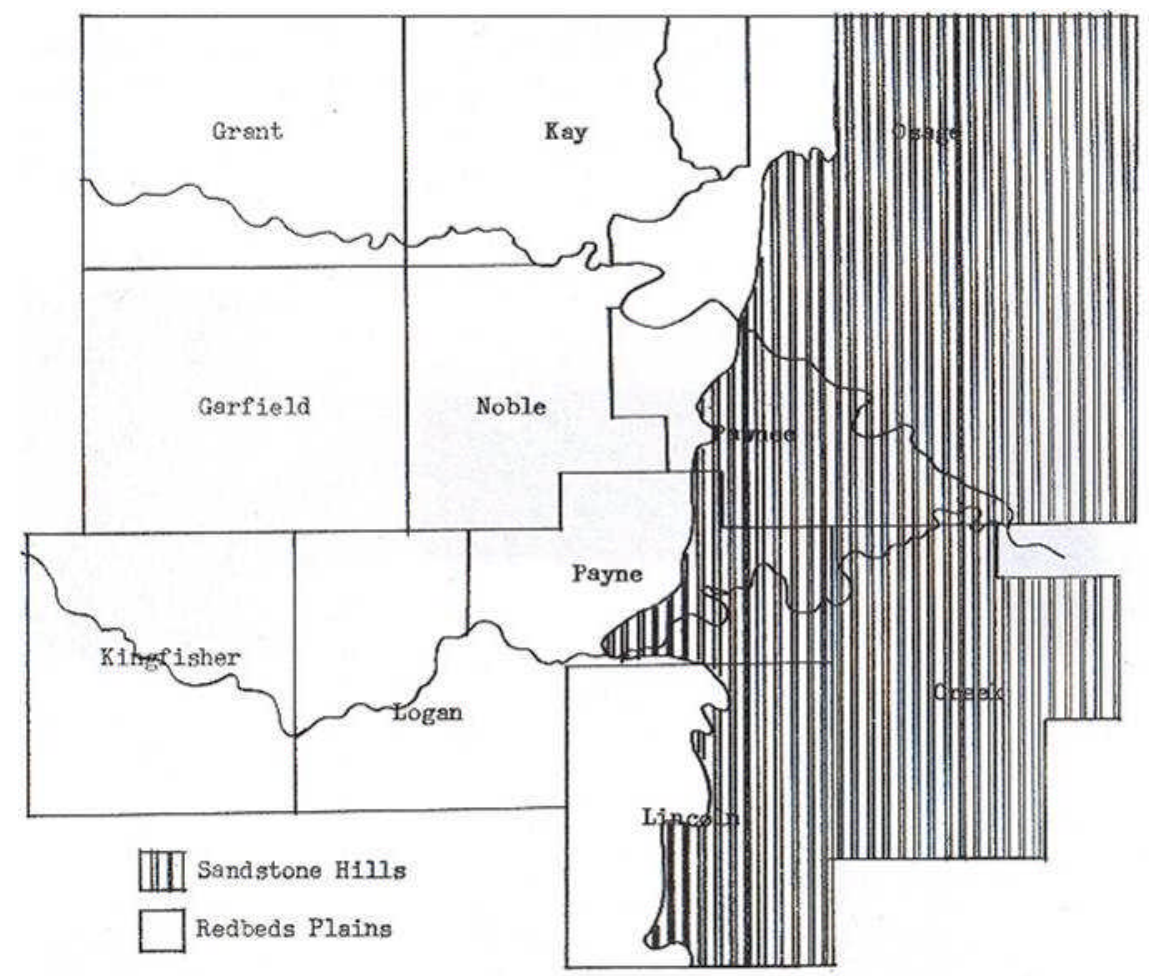

Flg. 2. Physiographic Regions of the Study Area

Keck, D.W. 
Volume 6, Number 1, December 2006

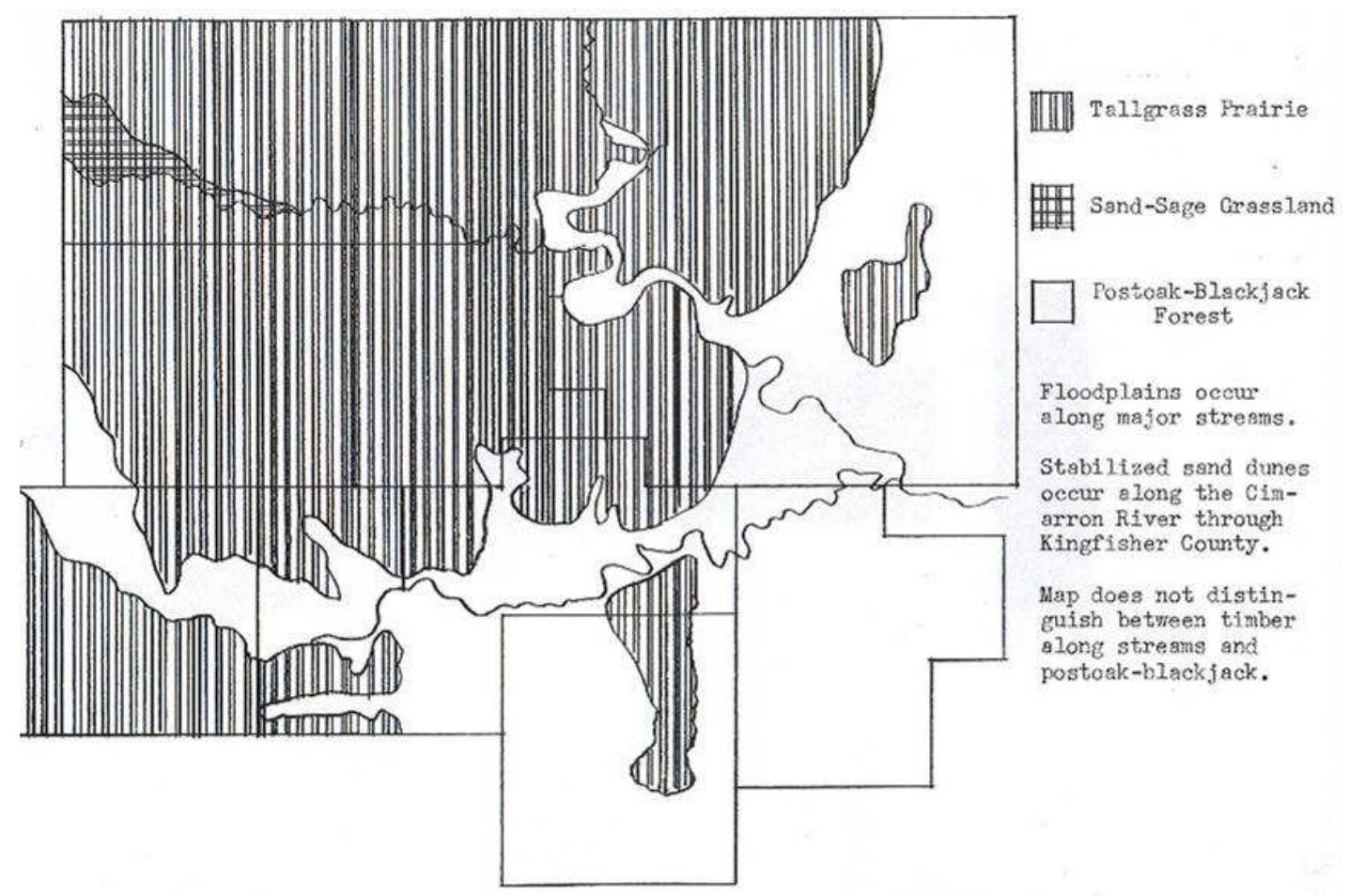

Fig. 3. A Vegetation Map of North Central Oklehoma

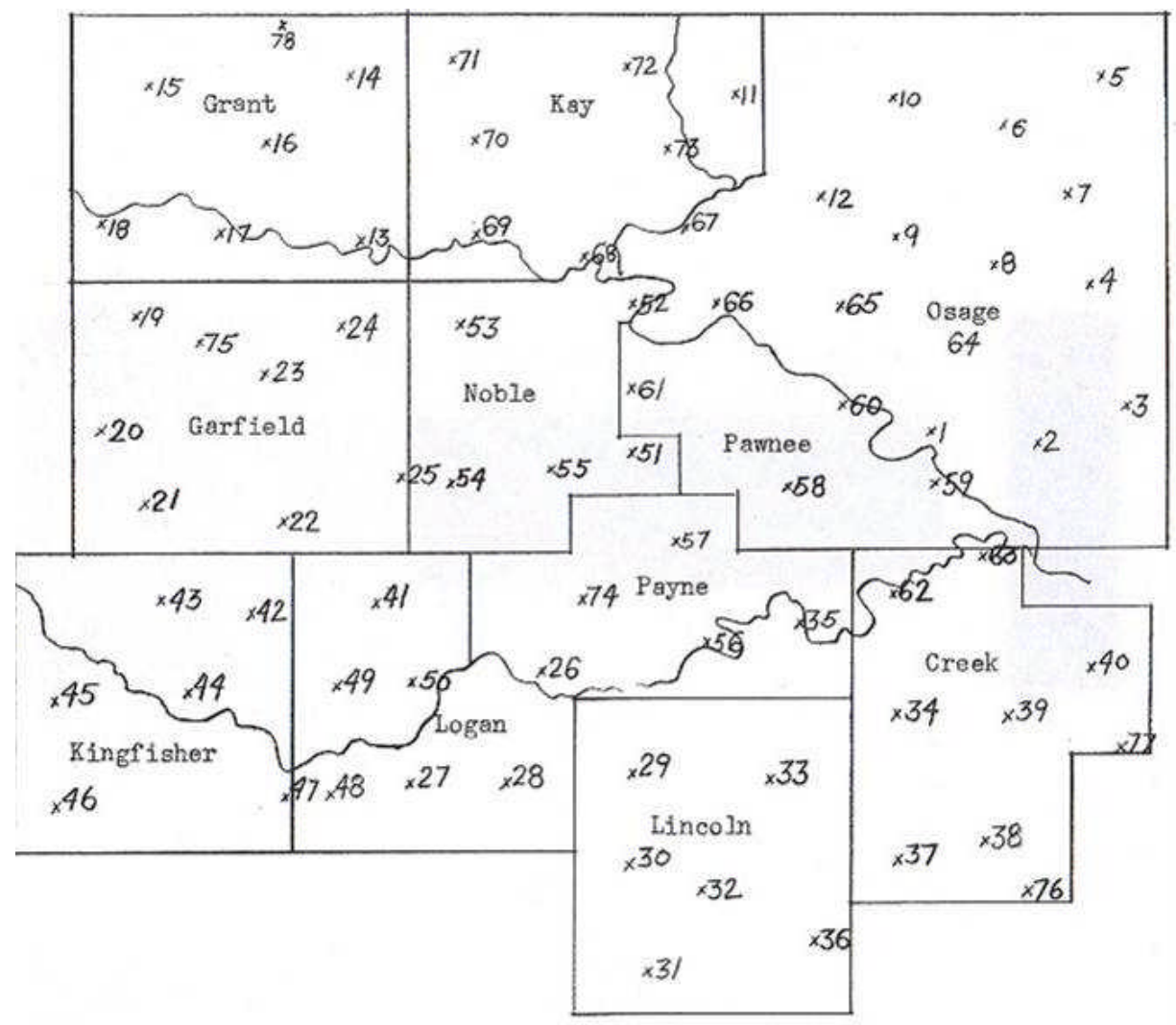

Fig. 4. Locetion of Collecting Sites

Keck, D.W. 


\title{
TAXONOMIC TREATMENT
}

\author{
Keys to Various Taxa
}

Key to Classes, Orders, and Families

1. Thallus of more or less definite form, usually with ascocarps. Ascolichenes

1. Thallus of entangled hyphae, without ascocarps . . • . . .

\section{Ascolichenes}

Lichenes Imperfecti

1. Hymenium produced in a perithecium . . . . . Pyrenulales

1. Hymenium produced in an apothecium

2. Thallus rudimentary; apothecia irregular, linear or oblong. . . . . . . . . . . . . . Hysteriales

2. Thallus commonly well developed; apothecia more or less round or cuplike.. . . . . . . . . . Lecanorales

\section{Pyrenulales}

1. Thallus crustose . . . . . . . . . Verrucariaceae

1. thallus squamulose or foliose. . . . . Dermatocarpaceae

Hysteriales

1. Apothecia without an exciple . . . . . . Arthonicaceae

1. Apothecia with an exciple. . . . . . . . Graphidaceae

Lecanorales

1. Phycobiont a species of Myxophyceae

2. Thallus squamulose to foliose, taking its form from that of the phycobiont . . . . . . . . . . . Collemaceae

2. Thallus foliose to granulose; not taking its form from the phycobiont

3. Thallus large, plainly foliose . . . . Peltigeraceae

3. Thallus smaller, somewhat foliose to granulose

4. Spores many per ascus . . . . . . Heppiaceae

4. spores 8 per ascus . . . . . . . Pannariaceae

1. Phycobiont a species of Chlorophyceae

5. Apothecia with both thalloid and proper exciples. . .

Diploschistaceae

5. Apothecia with either thalloid or proper exciple, but not with both

6. Thallus two-fold, having both squamules and podetia. .

6. Thallus otherwise

Cladoniaceae

7. Spores brown

8. Thallus crustose to scaly . . . . Buelliaceae

8. Thallus foliose. . . . . . . . Physciaceae

7. Spores hyaline

9. Spores very large, commonly up to 200 microns

Keck, D.W. 


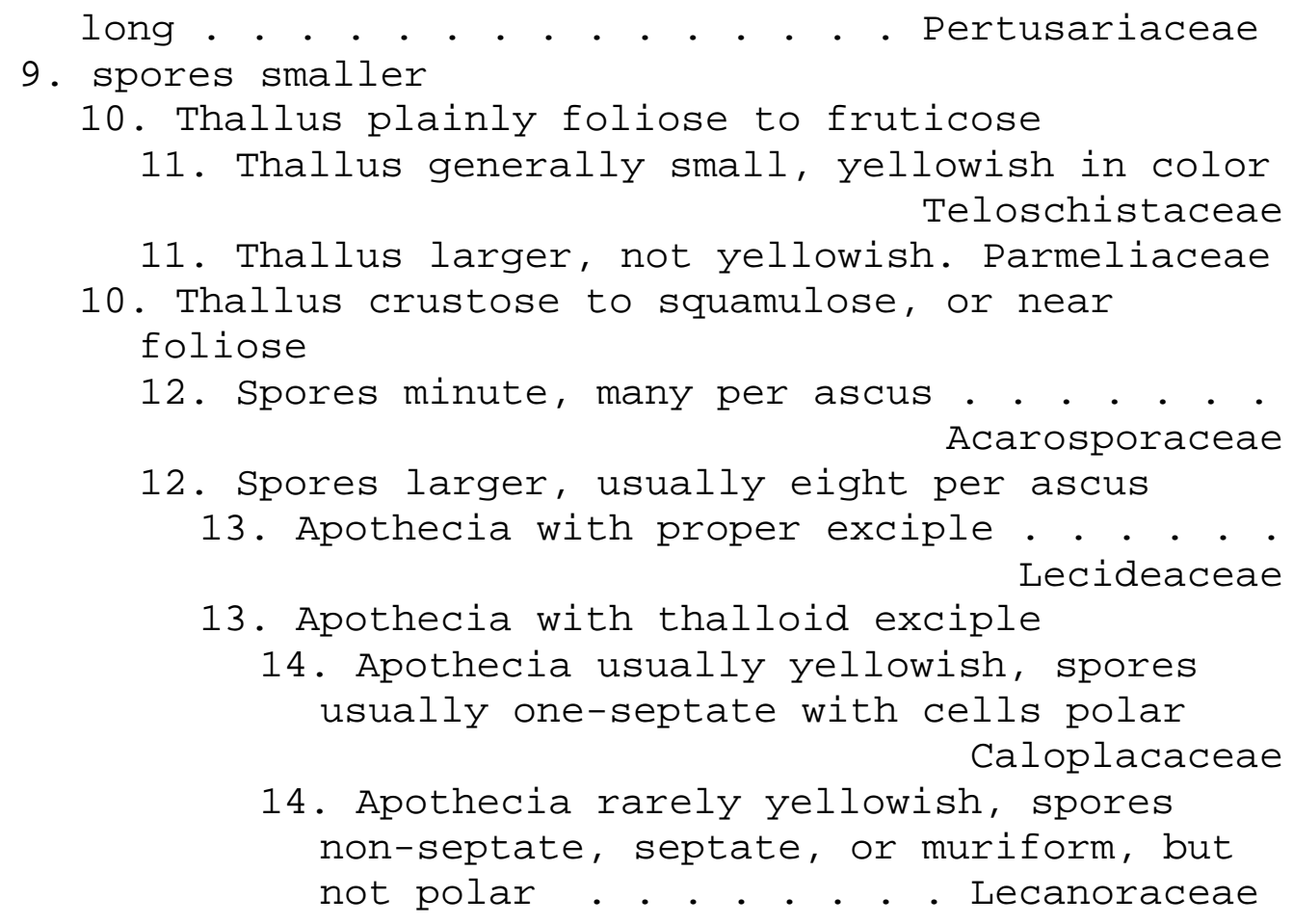

\section{Lichenes Imperfecti}

The only family representing this group is Leprariaceae. 


\title{
KEY TO GENERA AND SPECIES
}

\author{
Pyrenulales
}

Verrucariaceae

1. Spores non-septate . . . . . . . . 1. Verrucaria

1. Spores muriform. . . . . . . . . 2. Staurothele

1. Verrucaria

1. Thallus grayish-white . . . . . . . . . V. calciseda

1. Thallus brownish or greenish to black. . . V. nigrescens

2. Staurothele

1. Spores two per ascus. . . . . . . . . . S. umbrina

1. Spores eight per ascus . . . . . . . . . . diffractella

\section{Dermatocarpaceae}

1. Spores non-septate . . . . . . . . 1. Dermatocarpon

1. Spores muriform. . . . . . . . . . . 2. Endocarpon

1. Dermatocarpon

1. Thallus umbilicate, foliose. . . . . . . . D. miniatum

1. Thallus adnate, squamulose

2. Squamules round with elevated margins, not contiguous

D. hepaticum

2. Squamules lobed and overlapping. . . . . D. tuckermani

2. Endocarpon

The only species representing this genus is E. pusillum.

Hysteriales

Arthoniaceae

The only genus representing this family is Allarthonia and the only species is $A$. caesia.

\section{Graphidaceae}

The only genus representing this family is Graphis and the only species is $G$. scripta.

\section{Lecanorales}

collemaceae

1. Cortex of interwoven hyphae. . . . . . . . . 1. Collema

2. Cortex plectenchymatous. . . . . . . . 2 2 Leptogium

\section{Collema}

1. Thallus isidiate . . . . . . . . . . . C. subfurvum

2. Thallus without isidia. . . . . . . C. conglomeratum

2. Leptogium

1. Thallus brown to black, lobes crenate. . . L. chloromelum

2. Thallus bluish-slate colored, lobes entire. . L. cyanescens

Keck, D.W. 
Heppiaceae

The only genus representing this family is Heppia and the only species is $H$. hassei.

Pannariaceae

1. Thallus with lower cortex wanting. . . . . 1. Placynthium

1. Thallus with lower cortex. . . . . . . 2. Coccocarpia

1. Placynthium

The only species representing this genus is $P$. nigrum.

2. Coccocarpia

The only species representing this genus is $C$. cronia.

\section{Peltigeraceae}

The only genus representing this family is Peltigera and the only species is $P$. canina.

\section{Diploschistaceae}

The only genus representing this family is Diploschistes.

1. Proper exciple thick, radiately striate. . .D. actinostomus

1. Proper exciple thin, minutely toothed

2. Apothecia often $1 \mathrm{~mm}$ across, on soil and rocks. . . .

D. scruposus var. scuposus

2. Apothecia usually $0.3 \mathrm{~mm}$ or less, on moss and Cladonia sp. • . . . . . . . . . D. scruposus var. bryophila

Lecideaceae

1. Spores non-septate . . . . . . . . . 1. Lecidea

1. Spores septate . . . . . . . . . . . 2. Bacidia

1. Lecidea

1. Thallus crustose. . . . . . . . . . . L tesselina

1. Thallus squamulose

2. Squamules brownish to green on the edge . . L. rufonigra

2. Squamules whitish on the edge

3. Apothecia blackish. . . . . . . . . L. decipiens

3. Apothecia reddish-brown . . . . . . . L. russellii

2. Bacidia

1. Spores acicular. . . . . . . . . . . . . . B. umbrina

1. Spores fusiform . . . . . . . . . . . B. granosa

Cladoniaceae

The only genus representing this family is Cladonia.

1. Podetia extremely short or absent. . . . . C. apodocarpa

1. Podetia longer

2. Podetia repeatedly branched, squamules evanescent

3. Podetia dichotomously branched. . . . . C. subtenuis

3. Podetia variously branched, but not dichotomous. . .

C. uncialis

Keck, D.W. 
2. Podetia little branched, squamules persistent.

4. Podetia cup-shaped or trumpet-shaped

5. Podetia granular. . . . . . . . C. Chlorophaea

5. Podetia with fine, dusty soredia. . . C. fimbriata

4. Podetia not forming cups

6. Fruits at least twice as broad as the podetia. .

6. Fruits barely broader than the podetia . . . .

C. capitata

C. subcariosa

Acarosporaceae

1. Apothecia with thalloid exciple . . . . . 1. Acarospora

1. Apothecia with proper exciple . . . . . . 2. Sarcogyne

1. Acarospora

1. Thallus whitish-yellow to green. . . . . A. citrina

1. Thallus brown

2. Aeroles lobed, margins elevated . . . . A. fuscata

2. Aeroles entire, margins depressed . . . A. smaragdula

2. Sarcogyne

1. Apothecia pruinose . . . . . . . . . S. pruinosa

1. Apothecia not pruinose

2. Apothecia $0.2-1.0 \mathrm{~mm}$. across, red when wet. . S. simplex

2. Apothecia 0.7-2.0 mm. across, not red when wet $s$. clavus

Pertusariaceae

The only genus representing this family is Pertusaria.

1. Spores four per ascus. . . . . . . . . P. leioplaca

1. Spores one or two per ascus

2. Fruiting knobs sorediate . . . . . . . . multipuncta

2. Fruiting knobs esorediate

3. Fruiting knobs postulate, some finally opening into a disk. • . . . . . . . . . . . . . P. pustulata

3. Fruiting knobs not postulate, or if postulate, then not opening into a disk

4. Spores one per ascus. . . . . . . P. velata

4. Spores two per ascus. . . . . . . . P. pertusa

\section{Lecanoraceae}

1. Thallus yellow . . . . . . . . . . 1. Candelariella

1. Thallus not yellow

2. Spores aseptate. . . . . . . . . . . 2. Lecanora

2. Spores septate. . . . . . . . . . . 3. Lecania

1. Candelariella

1. Thallus persistent; on rocks. . . . . . . C. vitellina

1. Thallus evanescent; on trees. . . . . . C. xanthostigma

Keck, D.W. 


\section{Lecanora}

1. Epithecia intensely black . . . . . . . . . . L. atra

1. Epithecia variously colored, but not black

2. Thallus aerolate to squamulose. . . . . . . L. rubina

2. Thallus crustose or near-foliose

3. Thallus near-foliose. . . . . . . . L. muralis

3. Thallus crustose

4. Apothecia 0.1-0.25 mm. across. . . . L. piniperda

4. Apothecia somewhat larger to much larger

5. Apothecia pruinose

6. Spores subglobose, 9-15 microns wide... . .

6. Spores ellipsoid, 406 microns wide.. . . . .

L. hageni

5. Apothecia not pruinose

7. Apothecia yellowish to greenish . . . . . . L. varia

7. Apothecia light brown or darker

8. Thallus evanescent . . . . . . . . . . L dispersa

8. Thallus persistent

9. Apothecia light brown, exciples persistent. . . .

9. Apothecia dark brown to blackish,

L. subfusca

exciples often disappearing. . . . . L melaena

3. Lecania

1. Apothecia pruinose . . . . . . . . . . L. californica

1. Apothecia not pruinose . . . . . . . . L perproxima

Parmeliaceae

1. Thallus and apothecia yellow; spores many per ascus. . . .

1. Candelaria

1. Thallus and apothecia rarely yellow; spores eight per ascus

1. Candelaria

2. Parmelia

1. Exciple fibrillose below. . . . . . . . . . . C. fibrosa

1. Exciple not fibrillose

2. Thallus reduced to granulose squamules, or passing into a powdery crust . . . . . . . . . . . . C. concolor

var. effusa

2. Thallus granulose on margins only . . . . . C. concolor

$$
\text { 2. Parmelia }
$$

1. Soredia present

var. concolor

2. Medulla yellowish . . . . . . . . . P. obsessa

2. Medulla white

3. Soredia on upper surface . . . . . . . P. caperata

3. Soredia marginal . . . . . . . . . P. reticulata 
1. Soredia absent

4. Isidia present

5. Thallus yellowish-green. . . . . . . . P. isidiata

5. Thallus bluish or gray

6. Upper surface with white dots... . . P. rudecta

6. Upper surface without white dots. . P. haitiensis

4. Isidia absent

7. Thallus yellowish-green

8. Thallus tightly adnate . . . . . . P. conspersa

8. Thallus loosely attached . . . . P. stenophylla

7. Thallus bluish to gray. . . . . . . . P. borreri

Caloplacaceae

The only genus representing this family is Caloplaca.

1. Thallus sorediate

2. Soredia dull orange to blackish. . . . C. microphylina

2. Soredia yellow

3. Thallus smooth and continuous . . C. chrysophthalma

3. Thallus distinctly aerolate . . . . . . C. decipiens

1. Thallus esorediate

4. Thallus lobed at the margins

5. Exciple moderately thick and somewhat elevated. . . .

5. Exciple thin and not elevated." $\cdot \cdot \cdot \cdot \cdot \cdot c \cdot$. Iobulata

4. Thallus not lobed at the margins

6. Apothecia yellow, exciples whitish . . . C. ulmorum

6. Apothecia orange, exciple dull gray to yellow-green or orange

7. Exciple distinctly yellowish-green. . C. aurantiaca

7. Exciple gray or orange

8. Exciple gray, thallus well developed, areolate. .

8. Exciple orange, thallus scanty

C. arizonica

9. Apothecia crowded, angular, spores slightly curved. . . . . . . . . C. flavovirescens

9. Apothecia scattered, circular, spores not curved. . . . . . . . . . . C. cerina

Teloschistaceae

1. Thallus fruticose. . . . . . . . . 1. Teloschistes

1. Thallus foliose. . . . . . . . . . . 2. Xanthoria

1. Teloschistes

The only species representing this genus is T.chrysophthalmus.

2. Xanthoria

The only species representing this genus is $X$. candelaria.

Keck, D.W. 
Buelliaceae

1. Apothecia with proper exciples . . . . . . 1. Buellia

1. Apothecia with thalloid exciples . . . . . . 2. Rinodina

1. Buellia

1. Spores three-septate . . . . . . . . B. alboatra

1. Spores one-septate

2. Thallus of well-developed areoles

3. Areoles olive-brown. . . . . . . . B. novomexicana

3. Areoles greenish-gray to ashy

4. Hypothallus scanty or obsolete. . B. retrovertens

4. Hypothallus black, prominent

5. Exciple white initially, then turning darker. .

B. stigmaea

5. Exciple black. . . . . . . . . . . . . spuria

2. Thallus not areolate

6. Hypothecium colorless. . . . . . . . B. vilis

6. Hypothecium brownish

7. Hymenium colorless throughout. . . . B. schaereri

7. Hymenium brown above. . . . . . . B. punctata 2. Rinodina

The only species representing this genus is $R$. oreina.

Physciaceae

1. Medulla yellow to salmon-colored. . . . . . . . . Pyxine

1. Medulla white

2. Lower cortex well developed. . . . . . . . Physcia

2. Lower cortex poorly developed or wanting. . Anaptychia 1. Pyxine

The only species representing this genus is $P$. caesiopruinosa. 2. Physcia

1. Thallus esorediate

2. Thallus tightly adnate throughout. . . . P. syncolla

2. Thallus loosely adnate

3. Lobe tips thin and somewhat elevated. . P. aipolia

3. Lobe tips thickened and turned down

4. Whitish to gray, apothecia usually pruinose, on trees. . . . . . . . . . . . P. stellaris

4. Dark gray to blackish, apothecia not pruinose, on rocks. . . . . . . . . . . . P. halei

1. Thallus sorediate

5. Soredia in capitate patches on the upper surface

6. Thallus under two $\mathrm{cm}$. across, brownish, appearing crustose. . . . . . . . . . . . . P. elaeina

6. Thallus up to five cm. across, grayish, definitely foliose

7. Soredia white to pale blue. . . . P. tribacoides

7. Soredia grayish-green. . . . . . P. orbicularis 
5. Soredia along margins, and sometimes on the upper surface, but not in capitate patches

8. Thallus pruinose. . . . . . . . . . . . P. grisea

8. Thallus not pruinose

9. Lobes thin, flat, and often raised at the margins

P. millegrana

9. Lobes more or less rounded over the top with tips touching the substrate. . . . . . P. subtilis

1. Thallus sorediate

$$
\text { 3. Anaptychia }
$$

2. Hypothallus distinctly yellow. . . . A. heterochroa

2. Hypothallus gray to blackish . . . . . A. speciosa

1. Thallus esorediate

3. Thallus isidiate . . . . . . . . . A. granulifera

3. Thallus without isidia. . . . . . . . A. hypoleuca

\section{Lichenes Imperfecti}

Leprariaceae

1. Thallus often zonate, grayish-green . . . . 1. Crocynia

1. Thallus never zonate, bright yellow . . . . 2. Lepraria

1. Crocynia

The only species representing this genus is $C$. membranacea.

2. Lepraria

The only species representing this genus is L. chlorine.

Keck, D.W. 